Dzieje Najnowsze, Rocznik LIII - 2021, 4

PL ISSN 0419-8824

\author{
Michał Jerzy Zacharias \\ https://orcid.org/0000-0003-1677-0774 \\ Warszawa
}

\title{
Europejska droga od niepewności do niepewności: 1950-2017*
}

\begin{abstract}
Abstrakt: Michał J. Zacharias przedstawia pracę brytyjskiego historyka Iana Kershawa, poświęcona dziejom Europy w drugiej połowie XX w. i w pierwszych dziesięcioleciach XXI stulecia. Praca ma charakter syntetyczny. Należy podkreślić, że w ujęciu jej Autora dzieje Starego Kontynentu nie są prostą sumą dziejów poszczególnych krajów europejskich. Brytyjski badacz omawia przede wszystkim najistotniejsze problemy i zjawiska historyczne z perspektywy Europy. W jego rozważaniach liczą się głównie najważniejsze państwa i narody. Nie jest to pozbawione pewnej racji, bo przecież właśnie ich historia najlepiej oświetla, wyjaśnia przyczyny i przebieg, znaczenie i następstwa skomplikowanych wydarzeń i procesów historycznych.
\end{abstract}

Słowa kluczowe: powojenny podział Europy, „zimna wojna”, powojenna gospodarka, procesy integracyjne, kwestie społeczne, kontestacja lat sześćdziesiątych, kryzysy paliwowe z 1973 i 1979 r. oraz ich konsekwencje, przemiany kulturowe i mentalne, kryzys i upadek „realnego socjalizmu”, neoliberalizm, globalizacja, kryzys 2008 r. i jego następstwa, kryzysy w Europejskiej Wspólnocie Gospodarczej i Unii Europejskiej.

Abstract: Michal J. Zacharias presents the work of the British historian Ian Kershaw on the history of Europe in the second half of the twentieth century and the first decades of the twenty-first century. The work is a synthesis. It should be emphasised here that in Kershaw's view, the history of the Old Continent is not a simple sum of the histories of individual European countries. In the first place, the British researcher discusses the most critical problems and historical phenomena from the European perspective, which in his reflections are the

* Ian Kershaw, Rozdarty kontynent. Europa 1950-2017, tłum. Tomasz Krzyżanowski, Kraków 2020, Znak Horyzont, ss. 669; wyd. ang.: Roller-Coaster. Europe 1950-2017, London 2015, Penguin Books Ltd. 
most important states and nations. This is not without a specific reason because their history best illuminates and explains the causes and course, significance and consequences of complex events and historical processes.

Ke y w or d s: post-war division of Europe, Cold War, post-war economy, integration processes, social issues, protest of the 1960s, 1973 and 1979 oil crises and their consequences, cultural and mental changes, crisis and collapse of 'real socialism', neoliberalism, globalisation, 2008 crisis and its consequences, crises in the European Economic Community and the European Union.

Prezentowana praca jest kolejną syntezą brytyjskiego historyka Iana Kershawa ${ }^{1}$. Dotyczy dziejów Starego Kontynentu od pierwszych lat po zakończeniu II wojny światowej po zawirowania drugiej dekady XXI stulecia. Choć całkowicie odmienne, dzieje te były równie dramatyczne jak wydarzenia i procesy wcześniejsze, zdominowane przez dwie wojny światowe, rewolucje i kryzysy gospodarcze. Autor pisze, że powojenne losy europejskie charakteryzuja „ciagłe zwroty akcji, wzloty i upadki, nietrwałe zmiany, ogromne i wciąż przyspieszające tempo transformacji”. Przypominają one jazdę „kolejka górska [...], pełną emocji i momentów trwogi”. Z tą różnica, że podróż rollercoasterem „biegnie po stałym obwodzie i zatrzymuje się w ustalonym miejscu”. Natomiast powojenną historią Europy zdają się rządzić „niekontrolowane siły” kształtujące „życie praktycznie wszystkich Europejczyków” (s. 11). Jest w tej metaforycznej ocenie pewna doza literackiej przesady. Niemniej uważna lektura pracy pozwala przyznać w wielu wypadkach rację brytyjskiemu badaczowi.

Recenzowana synteza została napisana zgodnie z tymi samymi zasadami co poprzednia. Usiłując przedstawić skomplikowane, wielowątkowe zagadnienia w długim przedziale czasowym, Kershaw musiał wykorzystać prace głównie autorów zajmujących się problematyką poszczególnych krajów i zawężonych tematów. Lista prac wskazanych w bibliografii jest imponująca (s. 641-660). Niemniej dominują na niej dzieła przede wszystkim w języku angielskim, w zdecydowanie mniejszym stopniu sa zamieszczone prace niemiecko- i francuskojęzyczne. Książki autorów wschodnio- czy środkowoeuropejskich pojawiaja się jedynie sporadycznie. W rezultacie nie sposób oprzeć się wrażeniu, że Kershaw przedstawia bardzo brytyjskie czy szerzej - anglosaskie spojrzenie na dzieje Europy po katastrofie II wojny światowej.

Wyraźne podobieństwo do poprzedniej syntezy dostrzegamy również w konstrukcji pracy i metodzie badawczej Kershawa. Należy podkreślić, że oba te dzieła nie są podręcznikami, encyklopedycznymi zarysami czy

${ }^{1}$ I. Kershaw, Do piekła i z powrotem. Europa 1914-1949, tłum. A. Romanek, Kraków 2016, Znak Horyzont; wyd. ang.: To Hell and Back. Europe 1914-1949, London 2015; zob. art. rec. M.J. Zacharias, Pierwsza połowa XX stulecia. Europejska droga „do piekta i z powrotem”, „Dzieje Najnowsze” 2017, nr 4, s. 240-266. 
kompilacjami. Mogłoby je sugerować wykorzystanie jedynie wspomnianej literatury. Jednakże brytyjski historyk z powodzeniem unika sztucznego, mechanicznego zestawienia faktów oraz informacji zaczerpniętych $\mathrm{z}$ tych prac, a następnie przedstawienia ich $\mathrm{w}$ ciagach problemowych $\mathrm{w}$ zgodzie $\mathrm{z}$ intencjami poszczególnych autorów. W istocie wykorzystuje je tylko do własnej analizy wydarzeń i problemów, do własnych interpretacji różnorodnych procesów zachodzących w Europie. Traktuje je niemalże jak informacje źródłowe, tylko zaczerpnięte ze szczegółowych opracowań, a następnie podlegajace „obróbce” zgodnie z zasadami obowiązującymi każdego historyka. Czyni to czasem mniej, czasem bardziej udanie.

Treść omawianej pracy została zaprezentowana w układzie chronologicznym czy ściślej - chronologiczno-problemowym. W poszczególnych rozdziałach i podrozdziałach Kershaw przedstawia kolejne wielkie problemy, takie jak powojenny podział Europy, podporządkowanie środkowo-wschodniej części kontynentu Moskwie, „zimna wojna”, procesy integracyjne, powojenna gospodarka, kwestie społeczne, kontestacja lat sześćdziesiątych, kryzysy paliwowe z 1973 i 1979 r. oraz ich konsekwencje, kryzys i upadek ,realnego socjalizmu", przemiany kulturowe i mentalne, zwycięstwo tendencji neoliberalnych, globalizacja, kryzys 2008 r. i jego następstwa, migracje, islamski terroryzm, kryzysy w Europejskiej Wspólnocie Gospodarczej (EWG) i Unii Europejskiej, Brexit.

Takie podejście warunkuje sposób, w jaki zostały ukazane dzieje państw europejskich. W ujęciu Kershawa są one ważne o tyle, o ile są niezbędne do analizy, zrozumienia i prezentacji istotnych problemów i zjawisk historycznych. Liczą się wtedy najważniejsze państwa i narody. To właśnie ich historia najlepiej oświetla, wyjaśnia przyczyny i przebieg, znaczenie i następstwa skomplikowanych wydarzeń i procesów dziejowych. Dla przykładu - trudno przecież mieć wątpliwości co do tego, że początki integracji europejskiej były dziełem przede wszystkim Francuzów, Niemców i Włochów, ze Stanami Zjednoczonymi w roli inspiratora. A także co do faktu, że „zimna wojna” byłaby niemożliwa bez udziału Związku Sowieckiego. Podobnie jak rozkład i upadek „realnego socjalizmu” w Europie Środkowo-Wschodniej. I czyż to nie wydarzenia w największych i najsilniejszych krajach umożliwiaja poznanie mechanizmów kryzysu finansowego i gospodarczego, rozpoczętego w 2008 r.? W rezultacie więc należałoby stwierdzić, że w pracy Kershawa dostrzegamy zasadnicza, można by powiedzieć - strukturalna nierównowagę: dzieje mniejszych i średnich państw europejskich, i to po obu stronach „żelaznej kurtyny”, a także po wydarzeniach z przełomu lat osiemdziesiątych i dziewięćdziesiątych XX w. pozostają w cieniu historii najważniejszych krajów Starego Kontynentu.

Jednym $\mathrm{z}$ walorów pracy jest język. Książka została świetnie napisana i dodajmy - bardzo dobrze przetłumaczona. Autor z łatwością posługuje się piórem. Ma to znaczenie zwłaszcza wtedy, kiedy praca jest pisana w formie eseistycznej i adresowana do szerokiego kręgu czytelników, a nie wąskiego 
grona historyków, specjalistów. A także wtedy, gdy dotyczy ogromnej liczby faktów, problemów i procesów, niezmiernie złożonych i skomplikowanych, zrozumiałych jedynie wówczas, gdy zostaną precyzyjnie i klarownie zanalizowane, opisane i przedstawione.

W tym miejscu muszę stwierdzić, że w niniejszym, nawet stosunkowo obszernym artykule mogę się odnieść tylko do części problemów i zagadnień opisanych w pracy. Próba przedstawienia wszystkich musiałaby zakończyć się niepowodzeniem. Chciałbym więc skupić swą uwagę głównie na jednym, dominującym wątku, tj. wątku drogi, jaką przebyła Europa od powojennej niepewności do kolejnej, wyraźnie zarysowanej w pierwszych dekadach XXI w. Chciałbym także uwzględnić kwestie kultury, kontestacji i podziału kontynentu na przeciwstawne bloki i niektóre przynajmniej zagadnienia związane z dziejami ZSRS (od końca 1991 r. - Rosji) i państw, które w okresie „zimnej wojny" były podporządkowane Moskwie.

Ian Kershaw zauważa, że w pierwszych latach po zakończeniu wojny Europa była „biednym kontynentem”, zarówno na wschodzie, jak i na zachodzie (s. 182). Brakowało mieszkań, lekarstw, żywności, środków do życia² Do tego należałoby dodać powojenne migracje i wysiedlenia, brak stałej pracy dla wielkich rzesz ludności. W rezultacie bombardowań i działań wojennych „zniszczono olbrzymią część torowisk, stacji kolejowych, kanałów, mostów i dróg". W wielu miejscach zachodziła konieczność odbudowania „sieci gazowej oraz doprowadzenia energii elektrycznej i wody”. O tym wszystkim obszerniej Kershaw pisze w swej poprzedniej syntezie. Niemniej wiele $\mathrm{z}$ tych braków określało również położenie z początku lat pięćdziesiatych. Przecież racjonowanie żywności, np. w Wielkiej Brytanii, zniesiono dopiero w 1954 r. $^{3}$

Wspomniana sytuacja niewątpliwie sprzyjała pojawieniu się i występowaniu poczucia zagrożenia i niepewności ${ }^{4}$. Podobnie jak równoczesna ewolucja wydarzeń na arenie międzynarodowej. W skali światowej dotychczasowe mocarstwa europejskie stawały się $\mathrm{w}$ istocie podrzędnymi krajami, świat przestawał być europocentryczny, choć - jak myślę - jedynie politycznie i militarnie ${ }^{5}$. Zaczynała się era dwubiegunowości, również na Starym Kontynencie, dominacji Stanów Zjednoczonych i Związku Sowieckiego; era „zimnej wojny”, epoki, w której „pokój (był) niemożliwy, wojna nieprawdopodobna”, by

\footnotetext{
${ }^{2}$ Braki dotyczyły obszarów spustoszonych przez wojnę. Kontrastowały z dostępnością towarów, zauważalną np. we frankistowskiej Hiszpanii, choć i tu występowały wielkie skupiska nędzy. Zob. spostrzeżenia S. de Beauvoir, Siła rzeczy, tłum. J. Pański, Warszawa 2009, s. 38-41.

${ }^{3}$ I. Kershaw, Do piekta i z powrotem..., s. 571, 596.

${ }^{4} \mathrm{O}$ „poczuciu niepewności i tymczasowości”, „braku bezpieczeństwa”, „polskich strachach i lękach w okresie tuż powojennym” pisał M. Zaremba, Wielka trwoga. Polska 1944-1947. Ludowa reakcja na kryzys, Kraków 2017.

5 Trudno byłoby mówić o całkowitym zaniku znaczenia w obliczu szybkiej odbudowy gospodarczej i atrakcyjności kultury i stylu życia w zachodniej części Starego Kontynentu.
} 
użyć sformułowania francuskiego filozofa i socjologa Raymonda Arona ${ }^{6}$. Czy inaczej: zaczynała się epoka „gorącego pokoju”. W rezultacie Europa ulegała podziałowi, choć stwierdzenie Kershawa, że „jej obie połówki”, wschodnia i zachodnia, „były konstruktami czysto politycznymi”, zdaje się niezbyt trafne. Podobnie jak ocena „o wspólnej tożsamości kulturowej” obu tych części ${ }^{7}$. Zreszta $\mathrm{w}$ innym miejscu brytyjski historyk sam sobie przeczy, pisząc, że „nowa Europa” była podzielona „ideologicznie, politycznie i społeczno-gospodarczo" (s. 12, 23). Nie zmienia to faktu, że wyścig zbrojeń obu mocarstw, ich rosnące arsenały atomowe i jądrowe istotnie mogły jedynie pogłębiać lęki i poczucie zagrożenia. Zaczynała się pojawiać „egzystencjalna niepewność spowodowana zagrożeniem nuklearnym w latach 50. i na początku lat 60." (s. 22). Mając na myśli bombę atomowa, przywołany przez Autora George Orwell stwierdzi w 1945 r., że przyniesie ona „koniec wojen na wielka skalę osiagnięty kosztem przedłużającego się nieskończenie «pokoju, który nie jest pokojem»" (s. 23). Ta ocena okazała się trafna, lecz była sprzeczna z dominującymi odczuciami społecznymi na Zachodzie, wśród uczestników masowych ruchów antynuklearnych. To głównie w ich szeregach ujawniało się wspomniane poczucie zagrożenia i egzystencjalnej niepewności.

W optyce wspomnianych kręgów „wyścig zbrojeń przekroczył już dawno punkt” określany „niezwykle trafnym mianem wzajemnie gwarantowanego zniszczenia (mutually assured destruction)" (s. 36). W skrócie MAD, co niedwuznacznie sugerowało szaleństwo zbrojeniowe po obu stronach europejskiej barykady. Niemniej stwierdzenie Kershawa „o niepokoju wśród zwykłych obywateli” we wschodniej części kontynentu oraz ich przekonaniu, że „sowiecka potęga stanowi najlepsze zabezpieczenie przed natowska agresją" (s. 60), razi dosyć oczywistym brakiem trafności. Przecież w latach pięćdziesiątych, jak i później w Polsce czy na Węgrzech „sowiecka potęga” była uważana za głównego gwaranta ucisku narodowego oraz kwestionowanego systemu politycznego i społecznego. Tu niepewność i poczucie zagrożenia musiały się ograniczać do sfery sytuacji materialnej i faktu podległości Związkowi Sowieckiemu.

W rezultacie podziału obie części Europy prowadziły, jak można by powiedzieć, „żywoty równoległe”. Do czasu przemian zapoczątkowanych w 1989 r. różniły się ustrojowo oraz ideologicznie, wchodziły w skład odmiennych struktur politycznych, militarnych, gospodarczych. Wszystko to znajduje odzwierciedlenie w pracy brytyjskiego historyka. Trafnie podkreśla on znaczenie bardzo słabej odporności państw wschodnio- i środkowoeuropejskich na wstrząsy,

\footnotetext{
${ }^{6}$ R. Aron, Widz i uczestnik, z Raymondem Aronem rozmawiają Jean-Louis Missika i Dominique Wolton, tłum. A. Zagajewski, Warszawa 1992, s. 140.

${ }^{7} \mathrm{O}$ specyficznej sytuacji Europy Środkowo-Wschodniej, także kulturowej, na przykładzie Polski w ujęciu historycznym zob. J. Sowa, Fantomowe ciało króla. Peryferyjne zmagania z nowoczesna forma, Kraków 2011.
} 
różnego rodzaju kryzysy. Jego zdaniem wyraźne załamania gospodarcze czy też w istocie trwałe okresy słabości „państwowych gospodarek” tych krajów miały korzenie strukturalne. Wschodnio- i środkowo-wschodnie gospodarki były niewydolne, niekonkurencyjne, technologicznie przestarzałe, zbytnio zależne od przemysłu ciężkiego, kompletnie pozbawione elastyczności. „Nie mogły się radykalnie zmienić bez zmiany systemów politycznych [...] i nieugiętej ideologii”, która je „determinowała” (s. 320).

Taka ocena jest trafna jedynie częściowo. Przede wszystkim polityce w krajach rządzonych przez komunistów podlegały wszystkie dziedziny życia, nie tylko gospodarka. Ponadto dyskusyjna jest ocena roli „nieugiętej ideologii”. Z biegiem czasu ulegała ona coraz widoczniejszej erozji, minimalizacji, traciła „urok” legitymizacji, także wśród członków partii komunistycznych. Przynajmniej w niektórych krajach, jak Polska czy Jugosławia, ideologia stawała się $\mathrm{w}$ istocie przysłowiowym listkiem figowym, liczyły się głównie uwarunkowania geopolityczne oraz interesy rządzacych elit politycznych ${ }^{8}$. Razi także dosyć jednostronna narracja zdominowana przez problemy polityczne oraz liczne kryzysy - w 1953 r. (NRD), 1956, 1968, 1970, 1971 (Jugosławia), 1976, 1980-1981. W tym ostatnim przypadku przez powstanie Solidarności i wprowadzenie stanu wojennego w Polsce. Sprawy społeczne zostały prawie zupełnie pominięte. W odniesieniu do Polski czytelnicy nic się nie dowiedzą o zasadniczej przemianie struktury społecznej ${ }^{9}$, o powojennej odbudowie, likwidacji analfabetyzmu, urbanizacji, industrializacji, przekształceniu kraju rolniczego w przemysłowo-rolniczy, z przewagą ludności miejskiej. Niezależnie od faktu, że ze słabiutka, kompletnie niewydolna gospodarka, w zasadzie budowaną według starych, dziewiętnastowiecznych wzorców ${ }^{10}$. Całkowicie pominięta została również problematyka kulturalna, uwzględniona w przypadku Europy Zachodniej, choć miejscami z dosyć istotnymi brakami. Kershaw przedstawia dokonania twórców zachodnioeuropejskich, lecz całkowicie

8 Te ostatnie wnikliwie zanalizował i opisał Milovan Đilas w pracy Nowa klasa. Analiza systemu komunistycznego, tłum. A. Lisowski, Nowy Jork 1958, passim; zob. też: M.J. Zacharias, Idee, utopie, rzeczywistość. Myśl polityczna Milovana Đilasa (1911-1995), Bydgoszcz 2015, s. 179-219.

9 Tu wszystkich zainteresowanych należałoby odesłać do pracy A. Ledera, Prześniona rewolucja. Ćwiczenie z logiki historycznej, Warszawa 2014.

${ }^{10} \mathrm{Z}$ wyraźna preferencja przemysłu ciężkiego. Zawodząca w świecie zmierzajacym w stronę gospodarki opartej na najnowocześniejszych zdobyczach elektroniki i informatyki. Powielajacca rozwiązania sowieckie, co powoduje, że także do niej można odnieść trafną ocenę, iż ZSRS „prymitywny i mało elastyczny, potrafił dzięki tytanicznym wysiłkom zbudować najlepszą gospodarkę na świecie, ale wedle modelu z końca XIX w. Fakt, że w połowie lat osiemdziesiątych produkował $80 \%$ więcej stali, dwa razy tyle surówki i pięć razy tyle traktorów ile USA nie znaczył wiele, skoro nie potrafił dostosować się do gospodarki, która opierała się już na mikroprocesorach i programach komputerowych”. E. Hobsbawm, Wiek skrajności. Spojrzenie na Krótkie Dwudzieste Stulecie, tłum. J. Kalinowska-Król, M. Król, Warszawa 1999, s. 431. 
przemilcza osiagnięcia ich odpowiedników po drugiej stronie „żelaznej kurtyny”. A przecież zmiana sytuacji po śmierci Stalina, „odwilż” i jej konsekwencje oraz wydarzenia lat poprzedzających „praską wiosnę” umożliwiły powstanie wielu wybitnych dzieł w Związku Sowieckim, Polsce i Czechosłowacji, m.in. w dziedzinie filmu. Czytelnicy książki Kershawa nic się o nich nie dowiedza.

Wydaje się, że wspomniane braki w dużym stopniu wynikają ze słabego rozeznania brytyjskiego badacza $\mathrm{w}$ odpowiedniej literaturze przedmiotu. Dosyć często może to budzić zdziwienie, ponieważ dostępne sa także prace anglojęzyczne. Myślę, że gdyby Autor zapoznał się z książkami tak znanych historyków, jak Ivo Banac, Ante Čuvalo, Pedro Ramet (Sabrina P. Ramet), Dennison Rusinow i inni, to mógłby uniknąć wielu błędów i opuszczeń w przypadku Jugosławii1 ${ }^{11}$. Brak miejsca nie pozwala na wymienienie wszystkich. Wspomnę więc jedynie niektóre. Przede wszystkim nie do obrony jest teza, by po konflikcie z 1948 r. Josip Broz-Tito realizował w swoim kraju „formę socjalizmu diametralnie odmienną od zasad władzy sowieckiej” (s. 133). Wprost przeciwnie, zasadnicze cechy systemu jugosłowiańskiego, takie jak likwidacja własności prywatnej, jednopartyjny system polityczny, dominacja partyjnej biurokracji nad wszystkimi dziedzinami życia, były identyczne jak w ZSRS. Nieporozumienie stanowi także twierdzenie, że decentralizacja władzy federacyjnej przyniosła debiurokratyzację państwa. Doprowadziła ona jedynie do dyslokacji wpływów i władzy partyjnej biurokracji. Władza stopniowo przechodziła w ręce lokalnych, republikańskich ośrodków politycznych, nie mniej zbiurokratyzowanych jak centralny, federacyjny w Belgradzie. $\mathrm{Na}$ przełomie lat osiemdziesiątych i dziewięćdziesiątych stało się to jedna z głównych przyczyn rozpadu „realnego socjalizmu” w Jugosławii i samego państwa jugosłowiańskiego ${ }^{12}$. Błędna jest także ocena, że „Chorwacja była najzamożniejszą częścią Jugosławii” (s. 296). Pierwszeństwo w tym względzie należy przyznać Słowenii.

Uważna lektura pracy Kershawa umożliwia przeprowadzenie bardzo ważnego porównania. Chodzi o dostrzeżenie wyraźnego podobieństwa między działaniami Tity w czasie wewnętrznego kryzysu jugosłowiańskiego na przełomie lat sześćdziesiątych i siedemdziesiątych a późniejszą sytuacją w ZSRS w czasie rządów Michaiła S. Gorbaczowa. Brytyjski historyk na pewno nie

${ }^{11}$ I. Banac, The National Question in Yugoslavia. Origins, History, Politics, Ithaca-London 1984; idem, Post-Communism as Post Yugoslavism: The Yugoslav Non-Revolutions of 1989-1990, w: Eastern Europe in Revolution, red. I. Banac, Ithaca-London 1992; A. Čuvalo, The Croatian National Movement 1966-1972, Boulder 1990; P. Ramet, Nationalism and Federalism in Yugoslavia, 1963-1983, Bloomington 1984; S.P Ramet, Balkan Babel. The Disintegration of Yugoslawia. From the Death of Tito to the Fall of Milošević, Boulder 2002; D. Rusinov, The Yugoslav Experiment 1948-1974, London 1974. Brak miejsca nie pozwala wymienić wielu prac tych i innych badaczy, opublikowanych w języku angielskim.

12 Szczegóły zob. M.J. Zacharias, Komunizm, federacja, nacjonalizmy. System władzy w Jugosławii 1943-1991. Powstanie, przekształcenia, rozktad, Warszawa 2004, s. 397 i n. 
dostrzega niektórych, niekiedy zasadniczych szczegółów polityki Tity, ale w sumie dosyć dobrze przedstawia wydarzenia tzw. chorwackiej wiosny i okoliczności ściśle z nia związane. Stanowiły one pokłosie przekonania jugosłowiańskiego przywódcy o narastaniu kryzysu w SFRJ - politycznego, gospodarczego, narodowościowego. Lekarstwem miał być szeroki program reform, którego istotą była znacząca liberalizacja ustroju Jugosławii, inicjowana i wspierana przez Titę. Niemniej walki różnych frakcji w łonie aparatu władzy trwały nadal, nawet się potęgowały, sytuacja gospodarcza dalej wykazywała zasadnicze mankamenty, a separatyzmy i nacjonalizmy, głównie chorwacki, zaczynały zagrażać spoistości państwa. Sytuacja zdawała wymykać się spod kontroli. W rezultacie Tito zdecydował się na interwencję, początkowo w Zagrzebiu, przy użyciu służb bezpieczeństwa, policji, wspierających go polityków centralnego, federacyjnego szczebla i groźby użycia sił zbrojnych. Jugosłowiańska „pieriestrojka” przechodziła do historii. Jesienią 1971 r. zaczęło się zdecydowane „dokręcanie śruby”. W wyniku czystek krnąbrni politycy chorwaccy, a następnie w innych republikach musieli się pożegnać z władzą ${ }^{13}$.

Do pewnego momentu działania Gorbaczowa przypominały politykę Tity. Nowy sekretarz generalny równie dobrze dostrzegał skostnienie i niewydolność rodzimego ustroju: w gospodarce i szerzej - w funkcjonowaniu państwa i społeczeństwa. Jak pisze Kershaw, „sowiecki poziom życia należał do najniższych nawet wśród państw socjalistycznych" (s. 364). W tych warunkach trudno było rywalizować w wyścigu zbrojeń ze Stanami Zjednoczonymi Ronalda Reagana. Jak wcześniej Tito, Gorbaczow zainicjował więc liberalizację systemu, słynne uskorienije, głasnost i pieriestrojkę. Rozpoczą transformację polityczna, przemiany gospodarcze miały następować w późniejszym terminie. Wykluczał drogę chińską przyznająca prymat reformom gospodarczym. Nie sprzyjały mu okoliczności zewnętrzne, bowiem w rezultacie spadku cen gazu i ropy naftowej na rynkach światowych malały dochody w twardej walucie z eksportu.

Taka sytuacja miała przełożenie na malejący import żywności, co powodowało braki w zaopatrzeniu i ostatecznie „racjonowanie podstawowych produktów żywnościowych - w tym mięsa i cukru”. Malały także przychody podatkowe ze sprzedaży wódki, w wyniku nieopatrznie podjętej akcji antyalkoholowej. Siła rzeczy wywoływało to niezadowolenie. Pojawiały się także wyraźne nastroje odśrodkowe, niepokoje etniczne, żądania autonomii czy niepodległości. Związek Sowiecki pękał po „szwach narodowościowych”, jak wcześniej Jugosławia Tity. Gorbaczow chciał wzmocnić, reformować Związek Sowiecki, a przyspieszał jego upadek. Tym bardziej że choć mówił „o pilnej potrzebie reform, (to) nie miał w głowie jasnego planu" (s. 368). Wyraźny kryzys państwowości nie powodował jednakże próby cofnięcia biegu reform. Mimo podobieństw Gorbaczow nie był Titą. Pytanie, czy mógłby? Kershaw zdaje się temu przeczyć, pisząc, że sekretarz generalny „otworzył puszkę Pandory,

${ }^{13}$ Ibidem, s. 325-326, przypis 159 , s. 326-357. 
której wieka nie dało się na powrót zamknąć [...] zaczynał jako komunista; skończył jako socjaldemokrata na zachodnia modłę" (s. 366, 372). Niemniej jego politykę należy ocenić pozytywnie: otworzył przecież wrota do upadku imperium sowieckiego (choć chciał wzmocnienia swojego kraju), wspólnie z Reaganem i George'em H.W. Bushem wygasił „zimną wojnę” i umożliwił narodom Europy Środkowo-Wschodniej uwolnienie się z sowieckiego i komunistycznego ucisku. Wszystkie te procesy zostały opisane przez Kershawa.

Należy stwierdzić, że generalnie sposób przedstawienia problematyki wschodnio- i środkowoeuropejskiej pozostawia jednakże duży niedosyt. Razi pewną pobieżnościa, zdawkowością i schematyzmem. Zdecydowanie lepsze sa te partie pracy, które dotyczą Europy Zachodniej. Podobnie jak w poprzedniej syntezie, wyraźnie widać, że Kershaw „czuje”, rozumie przede wszystkim problemy zachodniej części kontynentu - polityczne, społeczne, gospodarcze i kulturowe. Dostrzega związki i zależności między nimi oraz przedstawia je wnikliwie i dokładnie, choć nie bez pewnych, często istotnych potknięć. Bardzo dobrze opisuje ewolucję ustrojową na Zachodzie w kierunku demokracji liberalnej. W dużym stopniu umożliwiały ją klęska i dyskredytacja nazizmu i faszyzmu oraz stosunkowo słaba pozycja komunistów. Nawet we Francji i Włoszech, gdzie istniały wielkie partie komunistyczne. Były one mocne, ale nie na tyle, by zaistnieć „jako rewolucyjna alternatywa dla liberalnej demokracji” (s. 65).

W rezultacie w krajach Europy Zachodniej zwyciężały partie szanujące reguły demokracji liberalnej: prawa człowieka, wolności osobiste i rządy prawa, a więc ugrupowania prawicowe i lewicowe: konserwatywne, liberalne, socjalistyczne i socjaldemokratyczne ${ }^{14}$. Bardzo wymowna w tym względzie była ewolucja socjaldemokracji niemieckiej. Na konferencji partyjnej w Bad Godesberg w 1959 r. porzuciła ona retorykę marksistowska, „w praktyce już od dawna pusta”, oraz wrogość wobec kapitalizmu i wyparła się „dotychczasowego ostatecznego celu, jakim była państwowa własność środków produkcji” (s. 88). W pełni akceptowała reguły demokratyczne. Podobnie jak w krajach skandynawskich, gdzie istniała gotowość wypracowania, w imię wspólnego interesu podstaw współpracy „pomiędzy światem pracy i kapitału”, jak i „politycznymi reprezentantami partii robotniczych i agrarnych” (s. 72). Istotna była także gotowość do przeprowadzenia czy też kontynuacji reform społecznych. W imię utrzymania „społecznego pokoju”, np. w Wielkiej Brytanii, gdzie po zwycięstwie w wyborach z 1951 r. konserwatyści utrzymali znacjonalizowane uprzednio przez labourzystów gałęzie przemysłu, a także rozbudowali Narodową Służbę Zdrowia $(\mathrm{NHS})^{15}$, rozszerzyli program

${ }^{14}$ Bardzo znamienna w tym względzie była postawa niemieckiej chadecji, która już w pierwszych latach po zakończeniu II wojny światowej chciała stworzyć w zachodnich strefach okupacyjnych „społeczeństwo, które łączyłoby demokrację i sprawiedliwość społeczna w ramach gruntownej reformy kapitalizmu na zasadach chrześcijańskich”. I. Kershaw, Do piekta $i$ z powrotem..., s. 603.

${ }^{15}$ NHS - National Health Service. 
budownictwa mieszkaniowego i „koncyliacyjnie podchodzili do potężnych związków zawodowych" (s. 77). W rezultacie, idąc śladem myśli Kershawa, można by powiedzieć, że jak bezpośrednio po klęsce nazistowskich Niemiec, następowała swoista „centryzacja” polityki wewnętrznej państw Europy Zachodniej. Skrajne siły i postawy polityczne, tak charakterystyczne dla międzywojnia, zanikały lub sytuowały się na obrzeżach, przestawały być alternatywa ustrojowa, widoczną w okresie międzywojennym.

Taka sytuacja sprzyjała procesom integracyjnym. Podobnie jak zbliżony potencjał ekonomiczny i wyraźne podobieństwa kulturowe, wnikliwie przedstawione przez Kershawa, między obywatelami państw, które początkowo utworzyły Europejską Wspólnotę Węgla i Stali, a następnie, w 1957 r. EWG. Miały one zapobiegać odrodzeniu międzywojennych nacjonalizmów, wybuchowi kolejnego wielkiego konfliktu zbrojnego, sprzyjać pojednaniu francusko-niemieckiemu, a także stanowić przeciwwagę dla Związku Sowieckiego, o czym myśleli przede wszystkim Amerykanie. Politycy amerykańscy wspierali „ideę zintegrowanej, zjednoczonej Europy, widząc w niej bufor przeciwko sowieckiemu komunizmowi” (s. 190).

W swoich wywodach Kershaw trafnie akcentuje zasadniczy dylemat, widoczny także w późniejszych procesach integracyjnych. Chodzi o trudności w pogodzeniu „ponadnarodowej organizacji”, „choćby ograniczonej współpracy gospodarczej, z niechęcią państw narodowych do wyzbywania się swojej suwerenności" (s. 188). Niemniej stwierdza, że takie obawy pozostawały w cieniu bieżących potrzeb, np. francuskiego dążenia do zintegrowania „Niemiec Zachodnich w europejskiej strukturze, zanim zdołałyby one odzyskać jakiekolwiek poważne znaczenie" (s. 192). Integracja była możliwa także dzięki „dalekowzrocznemu idealizmowi” (s. 189). Kershaw nie rozwija jednakże tej myśli, nie pisze, że chodziło tu głównie o Roberta Schumana, Konrada Adenauera i Alcide De Gasperiego. Pochodzili oni „z peryferii swoich krajów” i postrzegali integrację jako próbę „przezwyciężenia kryzysu cywilizacji, który zniszczył kosmopolityczną Europę ich młodości”" ${ }^{16}$. Zdaniem Kershawa integracja „od samego początku” była „projektem w równej mierze politycznym, co ekonomicznym" (s. 188). Traktaty rzymskie głosiły potrzebę stworzenia podstaw dla „coraz ściślejszego związku [podkreślenie - M.J.Z.] pomiędzy narodami Europy" (s. 196). Wszystkie te okoliczności nie wykluczaja faktu, że „skomplikowana prehistoria UE była kształtowana w mniejszym stopniu przez strategiczny zamysł - pisze brytyjski badacz - (co przez) improwizowane kroki i korekty powodowane nieprzewidzianymi w większości wydarzeniami" (s. 614).

Początki integracji zwiastowały nową epokę w dziejach Europy. Podobnie jak bezprecedensowe tempo rozwoju gospodarczego w zachodniej części kontynentu. Zdaniem Kershawa nie należy go traktować jako „normalnego”

${ }^{16}$ T. Judt, Powojnie. Historia Europy od roku 1945, tłum. R. Bartołd, Poznań 2008, s. 193. 
ożywienia wynikającego z „klasycznego cyklu koniunkturalnego” (s. 166). Rozwój był elementem globalnego wzrostu gospodarczego po wojnie, widocznego również w Japonii, Kanadzie czy Stanach Zjednoczonych. Po części wynikał z naturalnego „odbicia” po obu światowych konfliktach i wielkim kryzysie gospodarczym z przełomu lat dwudziestych i trzydziestych. Sprzyjały mu takie fakty, jak „uwolnienie zawieszonego [? - M.J.Z.] ${ }^{17}$ popytu”, tania siła robocza, wielki postęp technologiczny w czasie II wojny światowej, potrzeba odbudowy zniszczonych miast i wsi, ogromne inwestycje w technologię i siłę roboczą w najważniejszych dziedzinach gospodarki, wielka ekspansja międzynarodowego handlu, liberalizacja handlu, przyjęcie planu Marshalla i „odrodzenie międzynarodowych rynków” (s. 166-167).

Dla rozwoju nie bez znaczenia było także oddziaływanie teorii Johna Maynarda Keynesa ${ }^{18}$. Brytyjski ekonomista twierdził, że wzrost gospodarczy nastapi w rezultacie stymulacji, pobudzenia popytu, w dużej mierze poprzez interwencje państwowe w gospodarkę. I właśnie ta stymulacja istotnie zdawała się zasadniczą przyczyną rozwoju gospodarczego i towarzyszacego mu niespotykanego dotychczas poziomu życia, dobrobytu obywateli zachodnioeuropejskich krajów. W rezultacie w Wielkiej Brytanii między 1950 a 1955 r. dochód narodowy zwiększył się aż o 40\%, ustało racjonowanie żywności (w 1954 r.). W lipcu 1959 r. premier Harold Macmillan stwierdzał nie bez powodu, że „większość naszych obywateli nigdy nie miała się lepiej” (s. 78). $\mathrm{W}$ istocie było to zgodne z prawda, choć gospodarka na Wyspach rozwijała się stosunkowo słabo w porównaniu $\mathrm{z}$ innymi krajami zachodnioeuropejskimi, głównie z powodu niskiego poziomu inwestycji. Francuzi natomiast nazywali okres między 1946 a 1975 r. „trzydziestoma latami chwały” 19 , obywatele Niemiec Zachodnich - latami „cudu gospodarczego”, podobnie jak Włosi. W Republice Federalnej Niemiec „miliony biedaków”, które w pierwszych latach powojennych zbierały na ulicach „niedopałki papierosów po żołnierzach wojsk okupacyjnych”, kilkanaście lat później stawały się szanowanymi, zamożnymi ludźmi, wyjeżdżającymi „własnymi samochodami [...] na zagraniczne wakacje z twardą waluta - markami niemieckimi” (s. 90). Taka sytuacja musiała powodować jedynie pozytywne konsekwencje.

Wielkie tempo wzrostu gospodarczego umożliwiało sfinansowanie tzw. welfare state - państwa opiekuńczego, państwa dobrobytu. Bardzo szybko bowiem rosły przychody podatkowe, możliwe w wyniku niemalże pełnego zatrudnienia i radykalnego zwiększenia wydatków konsumenckich. Dzięki budżetom poszczególnych państw, które między 1950 a 1970 r. wzrosły dwudziestokrotnie,

${ }^{17}$ Kershaw ma tu na myśli prawdopodobnie oddziaływanie wielkiej siły nabywczej szerokich rzesz ludności, powstałej po II wojnie światowej.

${ }^{18}$ Wyłożonych przede wszystkim w pracy J.M. Keynesa, The General Theory of Employment, Interest and Money, New York 1935; wyd. pol.: Ogólna teoria zatrudnienia, procentu i pieniadza, tłum. M. Kalecki, S. Raczkowski, Warszawa 1956.

19 J. Fourastié, Les Trente Glorieuses; ou la révolution invisible de 1946 à 1975, Paris 1979. 
możliwe było utworzenie skutecznego zabezpieczenia społecznego „przed najgorszymi skutkami bezrobocia, inwalidztwa spowodowanego przez wypadki w pracy lub nędzy wynikającej ze starości” (s. 180-181), w tym ostatnim przypadku - systemu rent i emerytur. A także różnych zasiłków, głównie w celu zabezpieczenia wystarczającej opieki nad dziećmi. Myślę jednakże, że trudno byłoby mówić o „państwie opiekuńczym” za „żelazną kurtyną”. Polityka partii komunistycznych u władzy z reguły umożliwiała co prawda pełne zatrudnienie (w tym - ukryte), renty, emerytury i służbę zdrowia, ale w postaci zwykle niskiego poziomu zarobków, świadczeń i usług medycznych. Ponadto systemy zniewolenia narodowego, politycznego i obywatelskiego, sowieckie łagry, tłumienie siłą dążeń do wolności i niepodległości, jak na Węgrzech w 1956 r. i Czechosłowacji w 1968 r., utrzymywanie wielkiego i bardzo brutalnego aparatu bezpieczeństwa, systemu obozów przypominających „sowiecki Gułag z najgorszych, stalinowskich czasów" (s. 137) w okresie rządów Gheorghe Gheorghiu-Deja w Rumunii - to były fakty zupełnie niepasujące do pojęcia welfare state. Z tych samych przyczyn trudno mówić o istnieniu "srebrnego wieku” w bloku sowieckim, ustępującego tylko „złotemu” w zachodniej części kontynentu. Widać, że Kershaw nie przemyślał tych kwestii. Można by jedynie stwierdzić, że trwałymi i istotnymi pozytywami, przynajmniej w niektórych krajach, jak Polska, były likwidacja analfabetyzmu, powszechna edukacja (tysiąc szkół na tysiąclecie państwa) i rzeczywiście wybitne osiąnięcia na polu kultury. A także przemiany strukturalne w postaci wspomnianej już urbanizacji i industrializacji, czemu towarzyszyło przynajmniej częściowe, ale znaczące ograniczenie przeludnienia na wsi. Nie bez znaczenia były również powojenna odbudowa kraju oraz zagospodarowanie i integracja ziem zachodnich z reszta kraju.

Kolejne osiagnięcie i nowe zjawisko w zachodniej części kontynentu stanowiło pojawienie się tzw. społeczeństwa konsumpcyjnego. Dotychczas wysokie standardy materialne osiagały zazwyczaj górne warstwy społeczne, elity urodzenia, pieniądza, posiadania, wybitnych osiagnięć zawodowych, naukowych, artystycznych. Obecnie stawały się one dostępne szerokim rzeszom społecznym, posiadającym stałe i na tyle wysokie dochody, by nabywać towary z szybko rosnacej oferty dóbr materialnych - pralki, lodówki, telewizory, telefony, meble, samochody, nierzadko domy i mieszkania, jak i spędzać wakacje w atrakcyjnych miejscach, w kraju i za granica. Pojawiła się masowa turystyka, nota bene ratująca kulejąca, „zacofana gospodarkę Hiszpanii”, niepotrafiącej „wygrzebać się z kryzysu po latach dyktatury generała Franco" (s. 187). W rezultacie ludzie z różnych krajów zbliżali się „do siebie, jeżeli chodzi o styl życia, gusty i sposób spędzania wolnego czasu” (s. 183). Poznawali „inne kultury, obyczaje, potrawy i style życia”, uczyli się języków obcych. Wszystko to sprzyjało zanikaniu ignorancji, „tego niezbędnego warunku do uprzedzeń”, jak i „daleko idącej transformacji norm kulturowych” (s. 188) i pogłębieniu europejskiej integracji. 
Ostatecznie Europę Zachodnią „złotego wieku kapitalizmu” określały demokracja liberalna, procesy integracyjne oraz czynniki ekonomiczne i społeczne: wysokie tempo wzrostu gospodarczego, dobrobyt, welfare state, społeczeństwo konsumpcyjne. Te właśnie czynniki sprzyjały zanikaniu powojennego poczucia niepewności i zagrożenia, przynajmniej w sferze zaspokojenia potrzeb materialnych. Stwarzały także warunki do konsensusu społecznego w odniesieniu do ustroju, liberalnego mainstreamu i postępujaccej integracji.

Taka sytuacja, niemalże komfortowa, nie wykluczała jednak różnych form protestu i niezadowolenia. W latach sześćdziesiątych wyraźnie narastały buntownicze postawy tzw. baby boomers, a więc pokolenia urodzonego po wojnie. Do gwałtownej eksplozji doszło u schyłku lat sześćdziesiątych, przełomowy był rok 1968. Kershaw tłumaczy ja ogromnym wzrostem liczby studentów i niedopasowaniem infrastruktury do nowych warunków - brakiem wystarczającej liczby sal wykładowych i seminaryjnych oraz pracowników naukowych, jak i niemalże skoszarowaniem studentów „w bezdusznych betonowych dżunglach nowych kampusów uniwersyteckich” (s. 258). Buntownicze nastroje powodowały i pogłębiały także amerykańska interwencja w Wietnamie i brak wystarczającego rozliczenia z nazizmem w RFN. Zdaniem demonstrujących radykałów, przywódców studenckich i wielu szeregowych uczestników buntu „system polityczny i kapitalistyczna gospodarka” w Niemczech Zachodnich rzekomo miały być „kontynuacją faszyzmu”, narodowego socjalizmu, ten zaś - tylko wcześniejszym, najbardziej „ekstremalnym przejawem kapitalizmu", nadal panującego w Niemczech (s. 265, 266). Istotne stało się także ogólne przekonanie, że u władzy są czy też niedawno byli politycy kompletnie z innej epoki. Osoby takie jak gen. Charles de Gaulle i Adenauer, a jeszcze wcześniej Winston S. Churchill, po raz drugi premier w latach 1951-1955, zaawansowane wiekowo, mogły jedynie potwierdzać taką ocenę.

Wyżej przedstawione stwierdzenia Kershawa niewątpliwie są trafne. Niemniej zasadniczej przyczyny młodzieżowej rewolty, „otwartego buntu pokoleniowego" należy szukać głębiej, przede wszystkim w całkowicie odmiennych doświadczeniach życiowych, niedostatecznie akcentowanych przez Kershawa. Kontestatorzy nie przeżyli dwóch wojen światowych, rewolucji, kryzysów ekonomicznych, nie zaznali głodu i nędzy, dorastali w dobrobycie, mogli się kształcić. Później niż ich rodzice wchodzili w życie zawodowe, często pozostawali „w stanie zawieszenia między życiem studenckim a ciagle odkładanym życiem dorosłego człowieka". A także w stanie swoistej separacji, chociażby z racji wieloletniego pobytu w kampusach. Cechowała ich głęboka, również na poziomie międzynarodowym, „więź pokoleniowa”, stanowiąca „najbardziej uderzajaca cechę lat sześćdziesiątych” ${ }^{20}$. W rezultacie rosła, powstawała olbrzymia wyrwa, przepaść międzypokoleniowa: generation gap,

${ }^{20}$ G. Mak, W Europie. Podróże przez dwudziesty wiek, tłum. M. Woźniak-Diederen, Warszawa 2008, s. 622-623. 
niepowtarzalna, niespotykana na tę skalę w dziejach Europy czy szerzej świata zachodniego nie tylko XX stulecia. Zrewoltowana młodzież miała swoja subkulturę - muzykę, obyczaje, uczesania i ubiory, własne symbole i rytuały, często narkotyki. Mierziły ja przestarzałe i skostniałe struktury, polityczne i społeczne, obyczaje i konwenanse. Młodzi ludzie ambiwalentnie odnosili się do dobrobytu - chętnie z niego korzystali, choć równocześnie uważali, że społeczeństwo konsumpcyjne ma wybitnie represyjny i niewolaccy charakter. Ubezwłasnowolnia jednostki i wielkie ruchy społeczne, narzucając, „za pośrednictwem środków masowego przekazu, określony i dość jednorodny model postępowania, sukcesu, a nawet szczęścia” ${ }^{21}$. W rezultacie mówili i dążyli, głównie ich przywódcy, do rewolucji, przewrotu, mgławicowego w istocie. Ich działania, skorelowane z olbrzymimi robotniczymi i pracowniczymi strajkami, w maju 1968 r., wstrzassnęły podstawami ustroju Francji. Studenci mieli swoich idolów, rewolucjonistów z Ernestem „Che” Guevarą na czele. Chcieli zmienić, zrewolucjonizować społeczeństwo ${ }^{22}$. W odróżnieniu od hippisów wybierających jedynie drop-out, oderwanie od społeczeństwa i egzystencję zgodna z własnymi ideałami ${ }^{23}$, czego Kershaw w istocie nie dostrzega. Pisze natomiast o wystapieniach studentów za „żelazną kurtyną, głównie w Polsce. Dostrzega różnice $\mathrm{w}$ porównaniu z zachodnimi. Tu wolnościowe dążenia były równoznaczne z postulatami liberalizacji i demokratyzacji, całkowicie lekceważonymi przez kontestacyjną młodzież na Zachodzie. Nie zauważa jedynie, że polskie wystapienia z 1968 r. również miały charakter pokoleniowego buntu ${ }^{24}$.

Zdaniem Kershawa burzliwe wydarzenia lat sześćdziesiątych, głównie 1968 r., stały się „symbolem epoki zmian wartości kulturowych” (s. 279).

${ }^{21}$ K.T. Toeplitz, Najkrótsze stulecie. Szkic o XX wieku, Warszawa 2000, s. 194.

${ }^{22} \mathrm{~W}$ rezultacie dosyć często pojawiają się posądzenia zachodnich goszystów, przynajmniej ich przywódców, o komunistyczne sympatie. Jeśli miałyby one oznaczać aprobatę istniejących, zbiurokratyzowanych struktur „realnego socjalizmu”, to takie oceny trafiałyby w próżnię. Z reguły byli oni przeciwnikami „tworzenia ugrupowań typu leninowskiego”, niektórzy z nich (sytuacjoniści) wysyłali Moskwie i Pekinowi sygnały, że „ludzkość nie będzie szczęśliwa dopóki ostatni (komunistyczny) biurokrata nie zostanie powieszony na wnętrznościach ostatniego kapitalisty”. J.W. Müller, Przeciw demokracji. Idee polityczne XX wieku w Europie, tłum. J. Majmurek, Warszawa 2016, s. 245. Natomiast „Czerwony Dany”, czyli Daniel Cohn-Bendit, jeden z przywódców zrewoltowanych studentów paryskich, pytany przed sądem o imię i nazwisko, odpowiedział, że nazywa się Kuroń-Modzelewski. To także nie wskazywało na sympatię do zbiurokratyzowanego aparatu komunistycznej władzy. Komunistyczni włodarze w rodzaju Stalina, Breżniewa, Tity czy Gomułki w żadnym razie nie byli idolami kontestatorów na Zachodzie. Tym ostatnim można by co najwyżej zarzucać brak wyobraźni politycznej, niedostrzeganie, że rewolucyjne porywy, działania, symbolizowane przez „Che” i jego przyjaciół, zazwyczaj kończą się właśnie rządami zbiurokratyzowanego aparatu partyjno-państwowego, swoistej „nowej klasy”, dławiącej wszelkie wolnościowe aspiracje.

${ }^{23}$ G. Mak, op. cit., s. 625; K.T. Toeplitz, op. cit., s. 195-196.

${ }^{24}$ Zob. J. Eisler, Marzec 1968. Geneza, przebieg, konsekwencje, Warszawa 1991; idem, Polski rok 1968, Warszawa 2006. 
To właśnie wtedy - pisze - zaczynały dominować wolnościowe, egalitarne i antyautorytarne postawy i nastawienia, sposoby myślenia. Niemniej ocena, że „wspólna kultura była [...] głównym elementem definiującym kontynent europejski", jest bardzo dyskusyjna ${ }^{25}$. Podobnie jak przekonanie, że w „«dobrych czasach» prawie nieprzerwanego wzrostu i rosnącego dobrobytu [...], kultura europejska patrzyła głównie w przyszłość" (s. 205), że określały ją nastroje „powszechnego optymizmu” i wiary w nieograniczone możliwości rodzaju ludzkiego. W rzeczywistości często było inaczej, pojawiały się także głosy pełne różnych obaw, niepewności, głębokiego pesymizmu, nawiązań do niedawnej, tragicznej przeszłości. Zreszta sam Kershaw o tym pisze, stwierdzajacc, że w dziełach tak wybitnych dramaturgów, jak Samuel Beckett i Eugène Ionesco dominowały takie właśnie akcenty, pełne przeświadczenia, że „życie nie ma ani sensu, ani celu”; po prostu „jest absurdem”. To poczucie niewątpliwie pozostawało w związku „z niedawną przeszłością". Podobnie jak pisarstwo Alberta Camusa, nawiązującego „łączność z bezpośrednia, straszliwą przeszłością" (s. 212, 213). Identyczną wymowę miały filozoficzne dzieła Jean-Paula Sartre'a, dostrzegajacego nicość bytu ludzkiego, absurdalną egzystencję pozbawiona sensu i wszelkiego znaczenia ${ }^{26}$. Do niedawnej, międzywojennej i wojennej przeszłości nawiązywały dzieła Güntera Grassa, Carla Leviego, Curzia Malapartego i innych wybitnych pisarzy. Należałoby wspomnieć również o oddziaływaniu twórczości Orwella, w powieściach dystopijnych opisującego przyszłe totalitarne społeczeństwa. Zawierały one przemyślenia oparte na doświadczeniach wojny domowej w Hiszpanii i analizie sowieckiego komunizmu. W rezultacie zachodnioeuropejska kultura była pełna także pesymizmu i świadomości spustoszeń, tragicznych konsekwencji II wojny światowej - w psychice, mentalności, kulturze.

W swej pracy Kershaw przedstawia liczne dzieła i dokonania w dziedzinie muzyki, filozofii, literatury, filmu. Niemniej jego opisy często są dosyć schematyczne, ogólnikowe, pozbawione próby chociażby powierzchownej analizy, wyjaśnienia istoty treści i wymowy dokonań poszczególnych twórców. Tak jak w przypadku filmu Zmierzch Bogów Luchina Viscontiego, zasługującego na coś więcej niż stwierdzenie, że opisuje „stosunki rodziny przemysłowców z reżimem Hitlera", czy Powiększenia Michelangela Antonioniego, skwitowanego jedynie słowami „o sukcesie zarówno kasowym jak i artystycznym”, również z powodu „odważnych”, „jak na owe czasy [...] scen seksu” (s. 238, 239).

${ }^{25}$ Zob. przypis 7.

${ }^{26}$ Ta pesymistyczna ocena dotyczy jednakże tylko jednostki jako „bytu - w - sobie”, rzeczy lub podmiotu. Posiadając świadomość, stanowiąc „byt - dla - siebie” „jednostka” może nadać znaczenie swojemu życiu. To „wybór” jest „kluczowym, możliwym do zrealizowania elementem” takiej „filozofii”. To właśnie świadomość, nie fizyczna, bezsensowna egzystencja, tworzy człowieka. Jako świadoma istota może on zapewnić sobie „wolność” nie przez „subiektywne przyjmowanie danej mu sytuacji, lecz poprzez jej obiektywne kształtowanie drogą budowania przyszłości zgodnej z jego aspiracjami”. S. de Beauvoir, op. cit., s. 20. 
Uderza brak jakichkolwiek wzmianek o tak wybitnych twórcach, jak Joseph Losey, Luis Buñuel, Bernardo Bertolucci, Pier Paolo Pasolini, a także o dziełach inspirowanych młodzieżową kontestacja, takich jak Jeżeli Lindsaya Andersona, Swobodny jeździec Dennisa Hoppera, Woodstock Michaela Wadleigha. Dwa ostatnie filmy powstały w USA, ale wyraźnie odzwierciedlały postawy, nastawienia i mentalność znaczącej części także europejskiej, kontestującej młodzieży. Odczuwalny jest brak również choćby krótkiej analizy społecznego i kulturowego fenomenu w postaci filmów o Jamesie Bondzie. Ponadto czytelnicy pracy Kershawa nic się nie dowiedza, czy i jakie były analogiczne osiagnięcia w krajach Europy Wschodniej i Środkowo-Wschodniej - w dramaturgii, powieści, poezji, filmie i muzyce. To bardzo istotna wada tych partii książki, które zostały poświęcone kulturze. Za największą zaś należałoby uznać ograniczenie opisu osiagnięć w sferze kultury do „złotego wieku kapitalizmu”. $\mathrm{Z}$ pracy Kershawa nic się nie dowiemy, jak one wyglądały w kolejnych dekadach. A przecież w syntezie dziejów Europy potrzeba przedstawienia tych dokonań wydaje się dosyć oczywista.

O wiele lepiej niż opisy konkretnych, twórczych dokonań wypadła analiza przemian kulturowych. W potocznej świadomości, w sporach oraz polemikach światopoglądowych i politycznych, w poglądach szeroko pojętej prawicy, w Polsce i za granica, często pojawia się ocena, że to burzliwe wydarzenia, kontestacja z lat sześćdziesiątych, wyrażająca nowe systemy wartości, tj. postawy, nastawienia i zachowania, sposoby myślenia, idee i ideały, zapoczątkowała erozję, destrukcję tradycyjnych wartości, a więc wiary, rodziny, tradycji, patriotyzmu, i w końcu - że otworzyła drogę dla obecnej zapaści, kryzysu, a nawet upadku świata zachodniego - upadku kulturowego i cywilizacyjnego.

Należałoby stwierdzić, że trafność tej oceny bynajmniej nie jest oczywista. Nie została potwierdzona naukowo, często odzwierciedla jedynie polityczne oraz ideologiczne zacietrzewienie polemistów. Wywody autora prezentowanej pracy zaś zdecydowanie ją podważaja. Wynika z nich jasno, że przemiany kulturowe lat sześćdziesiątych i późniejszych zostały spowodowane tymi samymi przyczynami, czynnikami, co młodzieżowa rewolta, kontestacja, tj. długotrwałym okresem pokoju, dobrobytu, łatwym dostępem do edukacji, powszechną konsumpcja, masową turystyka, komunikacją, międzynarodowymi kontaktami, dostępem do nowoczesnych mass mediów, głównie telewizji, w późniejszych dekadach do elektronicznych środków przekazu. To właśnie one spowodowały gwałtowna, rewolucyjną erupcję nowego paradygmatu kultury, podważającego tradycyjne wartości. Zmianę wynikającą z istoty rzeczy: warunki egzystencji w ,złotym wieku”, jakże odmienne od przedwojennych i wojennych, musiały wywoływać zasadnicze zmiany w mentalności, stylu życia, hierarchii wartości społeczeństw zachodnich. Czy w długiej perspektywie czasowej były one katastrofalne, czy rzeczywiście doprowadziły do współczesnego kryzysu? Kulturowego i cywilizacyjnego? Czy istotnie mamy 
do czynienia z takim kryzysem? Myślę, że raczej należałoby mówić o istotnym przesileniu kulturowym i cywilizacyjnym. Natomiast twierdzenie o upadku cywilizacji zachodniej bardziej jest wynikiem ideologicznej i światopoglądowej postawy osób wypowiadających taką opinię niż rzeczywistej analizy faktów ${ }^{27}$.

Wyraźne przemiany kulturowe zaczęły się pojawiać, co istotne, jeszcze przed wybuchem kontestacji, w latach pięćdziesiątych. Może to jedynie potwierdzać wyżej przedstawioną tezę, że to nie młodzieżowa rewolta u schyłku lat sześćdziesiątych doprowadziła do zasadniczych przemian kulturowych i cywilizacyjnych w późniejszych latach. Zwiastowały ją jak i sama kontestację, gwałtowna ekspansja kultury popularnej, wszechobecnego kultu młodości, oddziaływanie filmów z udziałem Marlona Brando i Jamesa Deana, coraz widoczniejsze zanikanie sztywnego podziału na kulturę „wyższa”, dla elit, i „niższą", masowa, dla szerokich kręgów odbiorców. W kolejnej zaś dekadzie następował stopniowy, ale wyraźny zanik wartości i zachowań „starszego pokolenia, nawykłego do dyscypliny wyniesionej z czasów wojennych", takich jak „autorytet, posłuszeństwo i obowiązek” (s. 255). Tradycyjne instytucje i punkty odniesienia, jak ,armia, miejsca pracy, edukacja, religia i rodzina”, traciły swa moc wychowawcza, możliwości urabiania „zachowań i nastawień społecznych" młodego pokolenia. Powszechne było odrzucanie wszelkich hierarchii i instytucji opartych na hierarchicznej podstawie, idace w parze z widocznym pacyfizmem, pojawieniem się bardzo nośnego hasła make love, not war, z niechęcią do służby wojskowej. Z faktem, że to „świat cywilny”,

${ }^{27}$ Modelowym przykładem takiego sposobu rozumowania mogą być wywody Wojciecha Roszkowskiego w pracy Roztrzaskane lustro. Upadek cywilizacji zachodniej, Kraków 2019. Jego zdaniem rewolta lat sześćdziesiątych była „buntem nie tylko przeciw władzy, ale przeciw rzeczywistości”. Przyniosła „odrzucenie pochodzenia biologicznego w postaci rodziny, tożsamości społecznej, kulturowej w postaci tradycji oraz metafizycznej w postaci wiary w Boga”, a także zanik pojęcia „przyzwoitości” i „prawdy” oraz przyjęcie określenia „dekonstrukcja”, za francuskim filozofem Jacques'em Derrida, oznaczającego „możliwości dowolnych interpretacji każdego zjawiska”. W rezultacie obyczajowa rewolta lat sześćdziesiątych „przyspieszyła upadek cywilizacji zachodniej”. Ibidem, s. 213, 242, 251. Należy jednakże zauważyć, że takie rozumowanie, zgodne $\mathrm{z}$ obecna polityką historyczna polskiej prawicy, nie przybliża nas do zrozumienia fenomenu zarówno kontestacji, jak i przemian kulturowych w latach sześćdziesiątych. Nie wskazuje bowiem identycznych w istocie źródeł obu tych zjawisk. To nie kontestacja, lecz wymienione w tekście niniejszego artykułu uwarunkowania społeczne, całkowicie zmienione warunki życia, faktycznie w trybie niemalże rewolucyjnym, powodowały przemiany kulturowe, także w późniejszych dekadach. Nie wydaje się, by były one objawem upadku kultury, cywilizacji zachodniej. Pojęcie upadku oznacza przecież rozkład, rozpad realnie istniejących i funkcjonujących społeczeństw, narodów, państwowości, struktur i powiązań międzynarodowych (UE, NATO), zanik zdolności twórczych, umiejętności wytwarzania różnorodnych wartości. W zakresie tych ostatnich państwa zachodnie nadal znajdują się w czołówce światowej. Co najwyżej można by mówić o wyraźnym kryzysie bliskiego Roszkowskiemu wariantu kultury i cywilizacji, w praktyce - jednemu z wielu możliwych - co nie jest równoznaczne z upadkiem kultury i cywilizacji jako takiej, w tym wypadku - zachodniej. 
a nie „armia”, „wartości cywilne”, nie „militarystyczne” zaczynały kształtować postawy młodych i nie tylko młodych ludzi (s. 242, 352).

Negacja zhierarchizowanego i konserwatywnego świata godziła także w autorytet Kościołów, głównie katolickiego. Sprzyjała osłabieniu wiary, praktyk religijnych, postępom laicyzacji i sekularyzacji. Upowszechnienie edukacji, zdobyczy nauki i medycyny wywoływało podobne skutki, identycznie jak ,stały odpływ ludzi z prowincji do bardziej amorficznego społeczeństwa miejskiego”, do „rozległych zespołów miejskich” i „,wielkoprzemysłowej klasy robotniczej" (s. 245). Miasta kusiły różnorodnością i atrakcyjnym stylem życia, odciagały ludzi od religii i Kościołów, głównie katolickiego. Reformy Soboru Watykańskiego II nie przyniosły odwrócenia laicyzacyjnego trendu.

Rebelia przeciw staremu, zastanemu światu wyrażała powszechne pragnienie młodych ludzi wolności, niczym nieskrępowanej swobody. Zawołanie paryskich studentów z maja 1968 r. Il est interdit d’interdire (,zabrania się zabraniać") symbolizowało wszelkie kontestacyjne dążenia. Dotychczasowe zasady i konwenanse, nakazy i zakazy znalazły się w odwrocie. Zaczynała się era swobody obyczajów. Przysłowiowa „pigułka” wynaleziona w 1960 r. sprzyjała bujnemu życiu erotycznemu. Postępowało rozluźnienie więzów rodzinnych, wzrastała liczba rozwodów, niesformalizowanych związków. Stopniowo zanikały wszelkie tematy tabu. Skandalizująca powieść Davida H. Lawrence'a Kochanek Lady Chatterley, w wersji nieocenzurowanej wydana w 1960 r., wywołała oburzenie i przeciwdziałanie brytyjskiego konserwatywnego establishmentu, ale nie zahamowała „oszałamiającego sukcesu komercyjnego" (s. 252) i nie uniemożliwiła ekranizacji tego dzieła. Kilkanaście lat później identycznie zostało przyjęte epatujące seksem Ostatnie tango w Paryżu Bertolucciego, pominięte w pracy Kershawa. Niemniej często dostrzegano również istotne, negatywne strony epoki „cudu gospodarczego”, wyjałowioną egzystencję, pozbawiona istotnych wartości: intelektualnego i duchowego, metafizycznego wymiaru, jak w wybitnym, przejmujaccym filmie Federica Felliniego Stodkie życie. „Słodkie”, choć „w rzeczywistości puste, pozbawione sensu i odrażające” (s. 238). Ale czy takie wyjałowienie pojawiło się dopiero w erze „cudu gospodarczego" i kontestacji? To nie jest wcale oczywiste. Można by jedynie stwierdzić, że wcześniejsza bieda, wojny, kryzysy polityczne, społeczne i gospodarcze $\mathrm{w}$ jeszcze większym stopniu sprzyjały pustce i zapaści - duchowej i umysłowej. Ponadto: czy kiedykolwiek istniała epoka dominacji wartości wyższego rzędu w postawach ogółu tej czy innej społeczności?

Niezależnie od odpowiedzi na te pytania należy stwierdzić, że zmiany mentalne, kulturowe, obyczajowe, powstałe w burzliwych latach sześćdziesiątych, zostały pogłębione w kolejnych dekadach XX i XXI stulecia, także za sprawą tzw. postmodernizmu. To pojęcie jest wieloznaczne, zdaniem Kershawa oznacza przejście „od społeczeństwa przemysłowego do skomputeryzowanego świata technologii informatycznych i od "wysokiej» zwesternizowanej kultury do globalnej kultury masowej”. Określa różne rozbieżności, dysonanse, 
prawomocność sprzecznych interpretacji. Zaprzecza istnieniu obiektywnej prawdy, „obiektywnej rzeczywistości”, podkreśla znaczenie subiektywnych „dyskursów” (s. 390). Oznacza wzmocnienie permisywnych i relatywistycznych trendów, widocznych już w kulturze „złotego wieku”, wykazuje coraz większe znaczenie indywidualnych wyborów i indywidualistycznego stylu życia: „rozkład tego co wspólne i dominację tego, co indywidualne w społeczeństwie" (s. 390, 391).

Zwycięskie trendy postmodernistyczne występuja w okresie upowszechnienia elektronicznych środków przekazu. Kershaw docenia znaczenie kulturowego wpływu internetu, mediów społecznościowych. Nie zauważa jedynie, że w istocie oznaczaja one pojawienie się nowej ery - epoki wypierania gutenbergowskiej cywilizacji słowa drukowanego przez cywilizację słowa elektronicznego. W makroskali to przekaz elektroniczny, nie „drukowany”, wpływa już na myślenie, pragnienia, postawy i wybory, dominujace w szerokich kręgach społecznych. Niewątpliwie powiększa możliwości dostępu do informacji, nawiązywania kontaktów, upowszechniania zdobyczy nauki, techniki, medycyny, a także w dużym stopniu stymuluje przemiany gospodarcze i społeczne. Niemniej przynosi również negatywne konsekwencje: wyraźnie zwiększa możliwości manipulacji, inwigilacji, sączenia nienawiści, zamazywania prawdziwego stanu rzeczy; niweczy możliwości oddzielenia prawdy od fałszu. Niepokojąco często służy również infantylizacji i prymitywizacji zbiorowej mentalności, kultury, głównie dlatego, że media społecznościowe umożliwiają na masową skalę nie tylko odbiór informacji, co charakteryzowało dotychczasowe, tradycyjne środki przekazu. Obecnie, bez względu na swoja wiedzę, stopień wykształcenia i rzeczywiste kompetencje, każdy użytkownik internetu może być także nadawcą różnorodnych przekazów, a więc posiada możliwości wpływania na kształt opinii publicznej. Niewątpliwie więc trafna jest ocena, że media społecznościowe daja „prawo głosu” również „legionom imbecyli”; kultywuja, promują i satysfakcjonują głupotę, bo to się „dobrze sprzedaje" 28 . W rezultacie masowa promocja prymitywizmu i osobników, którzy go przedstawiaja, także w polityce, idąca w parze z deprecjacją wiedzy, umiejętności i kompetencji, staje się pierwszorzędnym, bardzo istotnym skutkiem rozwoju mediów społecznościowych. W tych warunkach przedstawione przez Kershawa postmodernistyczne „poczucie sceptycyzmu, relatywizmu i rozdrobnienia”, niemożliwości „wyjaśnienia, skąd przybywa społeczeństwo i dokąd zmierza" (s. 390), może ulegać wzmocnieniu. Należałoby powiedzieć, że na naszych oczach zaczyna się rysować bardzo niebezpieczna sytuacja: coraz bardziej ogłupiałe i otępiałe rzesze ludzkie muszą się konfrontować z postępująca komplikacją współczesnego świata. Czy mogą one sprostać wyzwaniom, lawinowo rosnącym trudnościom?

${ }^{28}$ Jest to opinia wybitnego pisarza włoskiego, Umberta Eco. Cyt. za: F.M. Cataluccio, Sposób na imbecyla, „Wolna Sobota”, dodatek do „Gazety Wyborczej”, 2-3 I 2021, s. 31. 
Początki zasadniczych trudności zachodnioeuropejskich można dostrzec w wydarzeniach wczesnych lat siedemdziesiątych, ściślej - w kryzysie naftowym z 1973 r. Zdaniem Kershawa był on „punktem zwrotnym” w powojennej historii Europy, zapoczątkował zmiany odciskajace "głębokie piętno na strukturach politycznych, ekonomicznych i społecznych". Przyniósł kres „optymizmu” charakteryzującego „poprzednie dwie dekady” (s. 305). W rezultacie konfliktu zbrojnego na Bliskim Wschodzie bowiem nastapiła redukcja dostaw ropy naftowej połączona $\mathrm{z}$ równoczesnym drastycznym wzrostem ceny tego produktu. Musiało to uderzyć w państwa zachodnioeuropejskie, ponieważ ropa zaspokajała ok. $60 \%$ ich zapotrzebowania na energię ${ }^{29}$. W rezultacie, w związku z niedoborami energetycznymi, pojawiły się recesja, wyhamowanie tempa wzrostu gospodarczego, spadek produktu narodowego brutto, inflacja, bezrobocie. To ostatnie słabe, śladowe w ,złotym wieku” (2-4\%), poszybowało do $12 \%$. Stało się problemem społecznym i politycznym. Niekiedy pojawiały się więc drakońskie środki zaradcze, jak w Wielkiej Brytanii w związku z konfliktem z tamtejszym Narodowym Związkiem Górników ${ }^{30}$ w 1974 r. Nastapiło wówczas wprowadzenie „stanu wyjątkowego, racjonowanie żywności”, pojawił się „trzydniowy tydzień pracy w przemyśle” (s. 314). Taką sytuację pogarszał kolejny kryzys gospodarczy, powstały w 1979 r., w konsekwencji rewolucji islamskiej w Iranie i wybuchu wojny między tym krajem a Irakiem rok później, a więc konfliktu dwóch wielkich producentów ropy. Uderzył on w gospodarki zachodnioeuropejskie, słabsze niż w 1973 r., co sprawiało, że recesja po tym kryzysie była „pod pewnymi względami bardziej dotkliwa”. Głównie z powodu podkopanego „morale”, narosłego „zaniepokojenia” i niezdolności rządów „do rozwiązania problemu «stagflacji»” (s. 317) ${ }^{31}$.

W powyższych kryzysowych okolicznościach następowało słabnięcie zainteresowania tradycyjnymi, Keynesowskimi rozwiązaniami gospodarczymi. Zdaniem Kershawa głównie dlatego, że wspieranie wzrostu przez stymulację popytu, „pompowanie pieniędzy w gospodarkę” oznaczałoby teraz, w zmienionych warunkach, ,jedynie zwiększenie presji inflacyjnej”, inflacji występującej w rezultacie żądań wzrostu płac bez równocześnie zwiększonej wydajności pracy (s. 310). Ostatecznie więc zaczynały zwyciężać odmienne koncepcje ekonomiczne. Miały one długa tradycję intelektualną, ich wczesnymi zwolennikami byli dwaj ekonomiści austriaccy: Ludwig von Mises i Friedrich von Hayek. Ten drugi w książce Droga do zniewolenia (The Road to Serfdom) łączył teorie socjalistyczne, postrzegane jako przymusowe interwencje zmierzające do zapewnienia równości, z planowaniem państwowym i zniewoleniem. Jego zdaniem tylko konkurencyjna, wolnorynkowa

\footnotetext{
${ }^{29} \mathrm{~W} 1950$ r. „ropa [...] zaspokajała 8,5\% procent zachodnioeuropejskiego zapotrzebowania na energię" (s. 305), wzrost był więc siedmiokrotny.

${ }^{30}$ NUM - National Union of Mineworkers.

31 „Stagflacji”, a więc równoczesnego występowania inflacji i stagnacji gospodarczej.
} 
gospodarka, wyzwolona spod państwowej kontroli, może być „kompatybilna z demokratyczna wolnościa” (s. 318).

Podobne poglądy głosił Milton Friedman w książce Kapitalizm i wolność (Capitalism and Freedom), opublikowanej w 1962 r. Był on „wiodacca postacia chicagowskiej szkoły ekonomicznej”. Mówił o potrzebie odrzucenia zarówno wszelkich państwowych ingerencji w gospodarkę w celu ożywienia popytu, jak i państwowych regulacji rynków przez politykę fiskalną. „Zamiast tego [...] proponował gospodarkę samoregulująca się za pomocą sił wolnego rynku", a także ograniczenie podaży pieniądza tak, by nie przekraczała poziomu produkcji i była utrzymana „w bliskiej zależności z produktem narodowym brutto”, co pozwoliłoby wyeliminować inflację. Jak pisze Kershaw, „ta monetarystyczna filozofia była rdzeniem tego, co później [...] zaczęto nazywać «neoliberalizmem»" (s. 317). Ogólnie jego zwolennicy zakładali, że długoterminowy wzrost zapewni gospodarka zderegulowana, a więc pozbawiona państwowej kontroli i interwencji, charakteryzująca się niskimi podatkami, konsekwentna prywatyzacją znacjonalizowanych gałęzi przemysłu i usług publicznych, redukcją sektora publicznego, wydatków budżetowych i świadczeń socjalnych.

W odniesieniu do Europy zastosowanie neoliberalnych koncepcji zazwyczaj wiąże się z rządami Margaret Thatcher (1979-1990). Zdaniem brytyjskiej pani premier „wolny handel i regulacyjne siły rynku” miały być „sposobem na narodowy dobrobyt i potęgę" (s. 326). Niemniej faktyczna praktyka polityczna konserwatystów niekiedy odbiegała od przyjętych wzorców. Zamiast maleć, podatki i wydatki publiczne w pierwszych latach thatcheryzmu wzrastały. Ostatecznie Thatcher udało się przede wszystkim przełamać potęgę związków zawodowych, zdusić inflację i deficyt, rozpoczać likwidację nierentownych gałęzi przemysłu, głównie górnictwa węglowego. Zdaniem Kershawa przywróciła ona równowagę brytyjskiej gospodarce. Wszystko to za cenę wysokiego bezrobocia, w 1983 r. przekraczającego $3 \mathrm{mln}$, i olbrzymiej polaryzacji społecznej, „alienacji i nienawiści u większości wielkoprzemysłowej klasy robotniczej”. „Po thatcherowskiej neoliberalnej agendzie” pozostało również dążenie do zmniejszenia wydatków państwa, prywatyzacji znacjonalizowanych gałęzi przemysłu i ograniczenia nakładów na świadczenia społeczne (s. 328, 329).

$\mathrm{W}$ latach osiemdziesiątych $\mathrm{w}$ mniej drastycznych formach neoliberalne tendencje zwyciężały w większości krajów zachodniej części Starego Kontynentu. Także w pofrankistowskiej Hiszpanii, gdzie socjalistyczny premier Felipe González wdrażał program oszczędnościowy przy użyciu „narzędzi monetarnych i fiskalnych do zduszenia inflacji i ograniczenia wysokiego deficytu w wydatkach rządowych”. Promował też „,większa elastyczność na rynku pracy” i obniżał „wydatki socjalne” (s. 350). We Francji zaś nowy prezydent od 1981 r. - François Mitterrand początkowo próbował stosować rozwiązania Keynesowskie, lecz po dwóch latach musiał z nich zrezygnować w obliczu wzrostu importu, wysokiej inflacji i rosnącego bezrobocia. 
Ostatecznie w ujęciu Kershawa obawa przed wysoką inflacją i wątpliwości, by w nowych okolicznościach „można było utrzymać poziom wydatków na państwo opiekuńcze" (s. 306), stanowiły główne przyczyny odrzucenia teorii Keynesa i zwycięstwa idei neoliberalnych. Taka diagnoza w dużym stopniu jest równocześnie trafna i wysoce niewystarczająca. Dużą rolę odegrały bowiem także inne czynniki. Mam na myśli niekorzystne tendencje demograficzne, tj. starzenie się zachodnich społeczeństw, biurokratyzację systemu państwa opiekuńczego, rosnące koszty jego utrzymania, demoralizację dużej części beneficjentów opieki społecznej, w tym migrantów oraz ich potomków. Od schyłku lat osiemdziesiątych nie bez znaczenia były też upadek „realnego socjalizmu" i rozpad Zwiąku Sowieckiego, do tej pory stanowiących alternatywę dla kapitalistycznej gospodarki rynkowej i demokracji liberalnej. W rezultacie pozbawione sowieckiego straszaka, neoliberalne elity miały ułatwione zadanie. Sprzyjały im również wspomniane już przemiany kulturowe, technologiczne i cywilizacyjne. Coraz powszechniejsza komputeryzacja i cyfryzacja, wyraźny przełom informatyczny, umożliwiający zdalne operacje finansowe w skali światowej, ułatwiały przecież globalizację ekonomiczna, idąca $\mathrm{w}$ parze $\mathrm{z}$ brakiem globalizacji demokratycznej. W praktyce oznaczało to, że zderegulowany, pozbawiony kontroli ze strony władz poszczególnych krajów, wielki biznes, a więc ogromne, często międzynarodowe molochy, globalne banki inwestycyjne, były niezależne również $\mathrm{w}$ przestrzeni międzynarodowej. Mogły osiagać i maksymalizować swe zyski bez potrzeby zabiegania o rozwój ekonomiczny tych czy innych krajów, podtrzymywania instytucji welfare state. Przeciwnie, jako niepożądane, systemy tego typu były bezpardonowo atakowane, uważano je bowiem za przeszkody w osiaganiu zakładanych celów, pożądanych maksymalnych zysków ${ }^{32}$.

W dłuższej perspektywie czasowej neoliberalna polityka, mniejsza lub większa aprobata działań godzących w zasady państwa opiekuńczego, państwowe regulacje $\mathrm{w}$ gospodarce, $\mathrm{w}$ redystrybucyjną rolę podatków w utrzymaniu równości, będzie stwarzać trudności partiom socjalistycznym i socjaldemokratycznym w utrzymaniu poparcia społecznego. Niemniej nie podważy jeszcze społecznego konsensusu dla zasad liberalnej demokracji, liberalnego mainstreamu politycznego i procesów integracyjnych w Europie. Co więcej, obalenie dyktatur na Półwyspie Iberyjskim, a następnie w Europie Wschodniej i Środkowo-Wschodniej zdawało się świadczyć o dobrym stanie europejskiej demokracji i faktycznym „końcu historii”, przynajmniej w odniesieniu do Starego Kontynentu.

Zdaniem Kershawa upadek systemu komunistycznego w Europie „nadał bardzo silny impuls globalizującej się gospodarce” (s. 519). Samo pojęcie „globalizacja” ma różne definicje. Nie była ona całkowicie nowym zjawiskiem, jako „pierwsza globalizacja” pojawiła się w połowie XIX stulecia, gdy „telegraf

${ }^{32}$ W literaturze polskiej zob. A. Walicki, Od projektu komunistycznego do neoliberalnej utopii, Kraków 2013, s. 402-404. 
i telefon, statki parowe i kolej umożliwiły ogromną ekspansję handlu na całym świecie" (s. 501) ${ }^{33}$. Brytyjski historyk pisze, że w ostatnich dekadach kolejnego, XX w. oznaczała „nie tylko integrację gospodarcza”, powstała w rezultacie „swobodnego przepływu kapitału, technologii i informacji, ale też przeplatanie się społecznych i kulturowych modeli postępu i przenikanie tychże ponad granicami poprzez rozwijające się części świata” (s. 20) ${ }^{34}$.

Taka definicja wydaje się trafna, zawiera zasadnicze atrybuty procesu globalizacyjnego, tj. integrację i współzależność. Myślę jedynie, że w tym miejscu silniej, wyraźniej należałoby podkreślić znaczenie trzeciego czynnika, zgodnego z trendami sygnalizowanymi już w latach siedemdziesiątych. Mam na myśli liberalizację gospodarcza, „a więc proces poszerzania i pogłębiania swobody [podkreślenie - M.J.Z.] wchodzenia rozmaitych podmiotów gospodarczych we wzajemne związki technologiczne, produkcyjne, handlowe, finansowe i inwestycyjne”, będące „niezbywalnym warunkiem wstępnym rozwinięcia dalszych i głębszych powiązań ekonomicznych" ${ }^{35}$. Kershaw wnikliwie i trafnie przedstawia globalizację w Europie, z tym że rozpatruje ją prawie wyłącznie w powiązaniu z wydarzeniami i zjawiskami zachodzacymi w zachodniej części kontynentu. Wyraźnie brakuje tu analizy podobnego procesu występujacego w Europie Wschodniej i Środkowo-Wschodniej. Kraje tego regionu nie miały własnych welfare states i po upadku „realnego socjalizmu” od razu zostały skonfrontowane i poddane wpływowi neoliberalnej i globalizacyjnej fazy rozwoju. Dobrze by było wyjaśnić, czy istotnie nie miały innej alternatywy, i określić, jakie były konsekwencje takiego oddziaływania.

Kershaw sygnalizuje pozytywne i negatywne strony globalizacji. Podkreśla, że „zapewniała (ona) materialne korzyści niewyobrażalne dla wcześniejszych pokoleń", sprzyjała rozwojowi handlu, wzrostowi gospodarczemu, łatwości komunikacji, podróży, dokonywaniu szybkich „transakcji finansowych i transferu kapitału”. Równocześnie przyspieszała procesy deindustrializacyjne, zastępowanie przemysłu przez usługi „w roli dominującego sektora gospodarki”. Ponadto ułatwiała relokacje „produkcji za granice, gdzie koszty pracy były niższe”, a więc „pomnażanie zysków” (s. 519, 520, 521). Trudno byłoby określić tę relokację całkowicie jednoznacznie jako pozytywne lub negatywne zjawisko.

Należy jednakże podkreślić, że szczegółowa analiza innych wydarzeń i zjawisk przedstawionych $\mathrm{w}$ pracy w związku z neoliberalna globalizacją skłania uważnego czytelnika do raczej pesymistycznych ocen i sądów. Negatywne strony przeważały nad pozytywnymi. Przede wszystkim globalizacja czy ściślej - liberalizacja zaczynała przynosić postępującą destabilizację społeczną

${ }^{33} \mathrm{O}$ początkach globalizacji zob. G. Kołodko, Wędrujacy świat, Warszawa 2008, s. 92 i n.

${ }^{34} \mathrm{~W}$ literaturze polskiej zob. ibidem, s. 92 i n.; R. Kuźniar, Pozimnowojenne dwudziestolecie 1989-2010. Stosunki międzynarodowe na przełomie XX i XXI wieku, Warszawa 2011, s. $136 \mathrm{i} \mathrm{n.}$

${ }^{35}$ G. Kołodko, op. cit., s. 100. 
i polityczna. Było to konsekwencją szybko rosnących dysproporcji dochodów, majątku, zamożności. Na biegunie ubóstwa stopniowo pojawiał się „nowy proletariat”, tj. dosyć różnorodne grupy ludzkie, których wspólnym mianownikiem były słabo opłacana praca, zatrudnienie na niestabilnych umowach, życie w kiepskich warunkach mieszkaniowych, znikome nadwyżki finansowe lub nieposiadanie ich wcale, i w rezultacie - łatwe wpadanie w długi. Szczególnie trudne stawało się położenie kobiet łączących „obowiązki rodzinne z kiepsko opłacana praca $\mathrm{w}$ niepełnym wymiarze lub oparta o umowę niedająca żadnych zabezpieczeń" (s. 523), a także wielu młodych ludzi wchodzących $\mathrm{w}$ dorosłe życie i niemogacych liczyć na powtórzenie sukcesu materialnego baby boomers, a więc pokolenia dorastajacego w „złotym wieku” pierwszych powojennych dziesięcioleci. Zjawiskom tym towarzyszyła malejąca dystrybucyjna rola państwa, w rezultacie obniżania wydatków i świadczeń społecznych. A przecież to właśnie dystrybucja państwowa decydowała o sukcesie welfare state. Egzystencja państwa tego typu stała pod znakiem zapytania także w związku z postępującym osłabieniem klasy średniej. Samo pojęcie „klasa średnia” jest mało precyzyjne, zazwyczaj określa się nim różne kategorie społeczno-zawodowe, usytuowane w środku społecznej hierarchii i wykazujące się odpowiednio wysokimi dochodami. Gdy klasa średnia jest liczna, zasobna i stabilna, to stanowi najlepszą gwarancję społeczną istnienia i funkcjonowania demokracji liberalnej. Gdy słabnie, maleje, pogrąża się w kryzysie, jak w międzywojniu, systemy demokratyczno-liberalne zaczynaja szwankować, ustępować miejsca rozmaitym autorytaryzmom, w skrajnych przypadkach - totalitaryzmom. A właśnie takie „szwankowanie” pojawiało się - i pojawia - w okresie dominacji neoliberalnej globalizacji; gospodarcze i społeczne trudności wywołuja skutki polityczne, choć jak na razie w ograniczonym zakresie. Szkoda, że wspomniana zależność, jak i w ogóle kwestia istnienia i postępującego osłabienia klasy średniej nie została w pracy przedstawiona właściwie, tj. z większą dozą wnikliwości i dokładności.

Zasadniczą cechą neoliberalnej globalizacji były głównie korzyści uzyskiwane przez wielki biznes, ogromne, międzynarodowe koncerny, technologiczne giganty, globalne banki inwestycyjne. Zdobywały one władzę, której żadne państwo nie było w stanie kontrolować, w czasie „gdy dla mniejszych firm (globalizacja) często oznaczała [...] kłopoty" (s. 523). Globalne molochy finansowe nie podlegały już żadnym kontrolom czy limitom, niegdyś narzucanym przez władze państwowe. W epoce turbokapitalizmu taka deregulacja sprzyjała głównie różnorodnym spekulacjom. Z wywodów Kershawa wynika, że to właśnie one, nie inwestycje, decydowały o formie i charakterze systemu kapitalistycznego na przełomie XX i XXI stulecia, o zyskach uzyskiwanych przez właścicieli tych gigantów, różnych nieruchomości oraz przez swoista klasę menedżerów i specjalistów, świetnie „obeznaną z zaawansowanymi technologiami”. Sprzyjały także powstawaniu ,jaskrawej przepaści między często absurdalnie wysokimi płacami, premiami i pakietami akcji najwyższych 
menedżerów wielkich firm i instytucji finansowych, a zarobkami przeważającej większości pracowników takich koncernów”; podobnie jak i pogłębieniu nierówności materialnych i społecznych, na skalę niespotykaną w „złotym wieku kapitalizmu”. W rezultacie ,potencjał dla społecznych niepokojów i politycznych wyzwań dla istniejącego systemu stawał się oczywisty" (s. 522, 525).

Wyraźna skłonność do spekulacji i „,chciwość” zaprzątająca „sektor finansowy”, spychające „na margines [...] wszelkie poczucie odpowiedzialności” (s. 552), wywoływały olbrzymie perturbacje gospodarcze, niewidziane od czasu wielkiego kryzysu z przełomu lat dwudziestych i trzydziestych XX w. Spekulacyjne udzielanie kredytów na zakup nieruchomości osobom mającym trudności ze spłata pożyczek doprowadziło do niebywałego krachu, zapoczątkowanego bankructwem amerykańskiego banku inwestycyjnego Lehman Brothers 16 IX 2008 r. W sytuacji gdy „globalna sieć inwestycji i kredytów była już [...] tak splątana”, załamanie finansowe w USA musiało „pociagnać za soba konsekwencje dla bankowości i finansów w innych krajach i dla światowej gospodarki”, także w Europie (s. 549). Szybko okazało się, że poszczególne państwa na Starym Kontynencie musiały zapewnić pomoc upadajacym bankom i w ten właśnie sposób próbować zapobiec całkowitej destrukcji finansowej. Byłaby ona nieunikniona, np. w Wielkiej Brytanii, gdzie w 2008 r. „łaczne aktywa czterech największych [...] banków były prawie cztery razy większe niż produkt krajowy brutto" tego państwa (s. 552).

Podobnie przedstawiała się sytuacja w innych krajach europejskich. $\mathrm{W}$ rezultacie rządowe ingerencje i interwencje były równoznaczne $\mathrm{z}$ wielkimi transferami pieniędzy podatników do banków. Ci natomiast w istocie dowiadywali się, że „sposób działania” ratowanych banków „niewiele się różnił od kasyn" (s. 554) i że podejmowane kroki potężnie zwiększyły zadłużenie kraju - jak w Irlandii. A także, że cięcia wydatków, nieuniknione przy takiej polityce, jedynie pogłębiały i przedłużały recesję w rezultacie „tłumienia popytu i ograniczenia wpływów podatkowych”. To zaś powodowało „dalsze cięcia” i wpędzało „gospodarkę w błędne koło”. Nie było bowiem pieniędzy „na bezpośrednie stymulowanie ożywienia gospodarczego”. Polityka „zaciskania pasa” zaprzątała „głowę niemal wszystkich ministrów finansów” (s. 561, 562, 563).

Głęboka recesja w Europie charakteryzowała się ujemnym poziomem wzrostu gospodarczego, bezrobociem, głównie wśród ludzi młodych, do 24. roku życia, spadkiem produkcji, we Włoszech - prawie o 25\%. Dotknęła w istocie wszystkie kraje ${ }^{36}$, choć w różnym stopniu. Głównie Hiszpanię, Grecję, Włochy, państwa bałtyckie, Irlandię. Pogłębiła zjawiska widoczne co najmniej od początku XXI stulecia, przede wszystkim narastający brak zaufania do partii i ugrupowań głównego nurtu politycznego. Powszechnie dostrzegano ich aprobatę neoliberalnej gospodarki, powodujacca ograniczenie zobowiązań

${ }^{36}$ W Europie Środkowo-Wschodniej pozytywnymi wyjątkami były Polska i Słowacja, o czym Kershaw pisze. 
państwa opiekuńczego, jak w „Agendzie 2010”, ogłoszonej w 2003 r. w RFN, w czasie rządów socjaldemokraty Gerharda Schrödera, w imię dostosowania się do „globalnie konkurencyjnej gospodarki”. Taką politykę w Niemczech kontynuowano następnie w okresie „wielkiej koalicji”, a więc rządów socjaldemokratów i chrześcijańskiej demokracji od 2005 r. W rezultacie „w oczach rosnącej liczby wyborców” niemiecka socjaldemokracja stawała się „nieodróżnialna od swoich konserwatywnych partnerów koalicyjnych" (s. 535, 536).

Podobna sytuacja pojawiała się również w innych państwach europejskich. „Główne partie” politycznego establishmentu zaczynały „wyglądać tak samo”, polityka stawała się bezalternatywna. Tak było m.in. w Wielkiej Brytanii, gdzie „deindustrializacja w fundamentalny sposób przeobraziła klasę robotnicza”, osłabiła związki zawodowe i tak słabe po epoce Margaret Thatcher, zmusiła niejako laburzystowskiego premiera Tony'ego Blaira do zjednania sobie „wyborców klasy średniej, dalekich od dotychczasowych bastionów Partii Pracy". Tym bardziej że w epoce głębokich przemian społecznych i kulturowych „dawna retoryka klasowa wydawała się anachroniczna, bo indywidualne przyzwyczajenia konsumentów i style życia przekraczały granice klasowe" (s. 531).

W rezultacie bezalternatywna polityka neoliberalna, utożsamiana z niepopularnymi cięciami, drastycznym ograniczeniem wydatków na cele publiczne, poważnie wpływała na bieg wydarzeń. Polityka stawała się coraz bardziej „niestabilna, polityczny krajobraz (zaczynał się) zmieniać”. Okazywało się, że „realna władza” nie należy „już do poszczególnych państw”, bowiem to „anonimowi manipulatorzy międzynarodowych finansów, posiadacze obligacji rządowych, agencje ratingowe i instytucje takie jak Międzynarodowy Fundusz Walutowy i Europejski Bank Centralny”, a więc główne podpory neoliberalnego porządku, określały „poziom i warunki wsparcia dla podupadających gospodarek" (s. 563, 564). To zaś powodowało spadek zaufania do liberalnego systemu politycznego, stwarzało szanse zyskania większego poparcia społecznego ugrupowaniom spoza mainstreamowego establishmentu. Zgodnie z trafną uwaga amerykańskiego badacza Davida Osta, że „nadmiar ekonomicznego liberalizmu zagraża liberalizmowi politycznemu. Poleganie wyłącznie na rynku, lekceważenie kwestii społecznych, związków zawodowych, umów i stosunków pracy każe ludziom szukać alternatyw. Kiedy więc partie twardo prorynkowe okazują się tymi samymi, które bronią liberalizmu politycznego i podstawowych praw obywatelskich [...], ci, którzy poszukuja alternatywy, skłaniają się ku partiom atakującym polityczny liberalizm jako zło i obiecują szybkie działania "mocnych ludzi», którzy ocalą naród”37.

${ }^{37}$ D. Ost, Odebrać PiS-owi niezadowolonych, https://www.academia.edu/20790634/Odebra\%C4\%87_PiS_owi_niezadowolonych (dostęp: 31 I 2021); zob. też: idem, Klęska „Solidarności”. Gniew i polityka w postkomunistycznej Europie, Warszawa 2007, passim. Podkreślając trafność spostrzeżenia Osta, należałoby zwrócić uwagę, że tzw. liberalna koncepcja ekonomiczna jest sprzeczna z istota liberalizmu. Andrzej Walicki pisze, że „wyznawcy liberalizmu jednostronnie gospodarczego", a więc neoliberałowie bezzasadnie zawłaszczyli 
Chodzi tu o ugrupowania niezbyt precyzyjnie zwane populistycznymi, zarówno lewicowe, jak i prawicowe, w Europie Środkowo-Wschodniej wyraźnie premiujące różne formy autorytaryzmu ,w narodowo-konserwatywnym wydaniu" (s. 565). Niekiedy są to partie wyraźnie niepoważne, jak „nowa partia protestu pod wodzą komika Beppe Grillo” we Włoszech (Ruch Pięciu Gwiazd), zyskująca „jedną czwartą głosów” wyborczych (s. 567).

Powyższe ugrupowania najczęściej głoszą potrzebę przeciwstawienia się ponadnarodowym instytucjom, bankom i koncernom oraz własnym rządom, osobistościom głównego nurtu politycznego, oskarżanym o złe zarządzanie gospodarka. Przedstawiciele tych partii często podkreślają również konieczność obrony tożsamości i interesów narodowych. W tym ostatnim przypadku głównie w obliczu olbrzymiej fali terroru i migracji, powstałej w rezultacie destabilizacji sytuacji na Bliskim Wschodzie i w północnej części Afryki.

Ostatecznie rozważania Kershawa umożliwiają sformułowanie wniosku, że kryzysowe i pokryzysowe wydarzenia wykazuja znaczne osłabienie głównych filarów społecznego i politycznego konsensusu z pierwszych powojennych dziesięcioleci: możliwości wzrostu gospodarczego, powszechnego dobrobytu, ugody kapitału i świata pracy, dostępności świadczeń w ramach welfare state, a także akceptacji zasad demokracji liberalnej i procesów integracyjnych w Europie. Okazuje się, że poczucie zagrożenia socjalnego, tożsamościowego i narodowego jest większe niż satysfakcja z niewątpliwych osiagnięć całej powojennej epoki: egzystencji „w pokoju i wolności, pod rządami prawa” i mimo wszystko - „we względnym dostatku” (s. 611). Na Starym Kontynencie historia zakreśla koło, zaczynaja powstawać różne obawy, nastroje zagrożenia i niepewności, większe „niż kiedykolwiek od czasu zakończenia drugiej wojny światowej” (s. 618). Można powiedzieć, że ludzie pozbawieni elementarnej pewności, elementarnego poczucia bezpieczeństwa, w stanie głębokiego stresu egzystencjalnego, zaczynaja występować przeciwko dotychczasowemu systemowi i poszukiwać zbawców we wspomnianych partiach populistycznych, autorytarnych czy nacjonalistycznych. Ich obawy rodzą się także w związku z napiętą sytuacją międzynarodowa, zmianami klimatycznymi, potrzeba zapewnienia odnawialnych źródeł energii, zapaścią demograficzna, migracja, wielokulturowościa, rosnącymi rozpiętościami w zamożności i dochodach, kruszejąca spójnością społeczna, nierozwiązanymi kwestiami bezpieczeństwa,

sobie pojęcie liberalizmu. Nie bacząc, że właściwym podmiotem wolności, stanowiącej jądro każdego liberalizmu, jest jednostka ludzka. Tymczasem obecnie wolność nie jest nawet wolnością producentów, ale wolnością „rynków finansowych”. Te zaś dążą „bez skrupułów do maksymalizacji własnych zysków” i bezwzględnie panują zarówno nad jednostka, jak i całymi społeczeństwami. W rezultacie praktyki neoliberalne rozmijają się z wolnościa, z podstawowymi zasadami liberalizmu. O destrukcyjnych mocach tzw. neoliberalizmu zob. A. Walicki, Od projektu komunistycznego..., zwłaszcza s. 319-424; idem, Neoliberalna rewolucja, „Gazeta Wyborcza”, 30 XI - 1 XII 2013, s. 30-31; idem, Bez sprawiedliwości nie ma wolności, „Przegląd”, 9-15 XII 2013, s. 8-12. 
coraz większą inwigilacja. Nie bardzo wiadomo, czy i jak można by rozwiązać te problemy. Państwa narodowe sa do tego niezdolne, Unia Europejska zaś z pewnością jest „wielkim osiagnięciem”, ale też „dziełem niedokończonym [...] instytucją obarczoną wieloma wadami i słabościami” (s. 630). W rezultacie „nie sposób przewidzieć, co stanie się w kolejnych dekadach. Wiemy jedynie, że nic nie wiemy. Niepewność pozostanie kluczową cechą współczesnego życia. Charakterystyczne dla historii Europy spektakularne wzloty i upadki, zakręty i zawirowania będę jej z pewnościa nadal towarzyszyć" (s. 634). Skądinąd taka sytuacja wydaje się zgodna z naturalnym biegiem rzeczy. Bo przecież, jak pisał już Immanuel Kant w 1784 r., ,z pokrzywionego drzewa człowieczeństwa nie da się wyciosać nic prostego" (s. 611).

Pracy Iana Kershawa nie można ocenić jednoznacznie. Podobnie jak jego synteza, poświęcona dziejom Europy w pierwszej połowie XX w., jest tyle imponująca, co niedoskonała. Ta ostatnia, krytyczna uwaga odnosi się do sposobu przedstawienia wewnętrznej problematyki państw środkowoeuropejskich, w pewnym stopniu także Związku Sowieckiego, a później Rosji. Tu wywody Autora często są dosyć nieliczne, przypadkowe i powierzchowne, pozbawione wnikliwości i dokładności, widocznych w opisie dziejów zachodniej części kontynentu, globalizacji, zjednoczenia Niemiec, niektórych aspektów rozpadu „realnego socjalizmu” w Europie Wschodniej i Środkowo-Wschodniej, zakończenia „zimnej wojny”. Pozwalają one zrozumieć naturę wyzwań, także kulturowych i cywilizacyjnych powstałych w ostatnich dekadach, po przesileniu z przełomu lat osiemdziesiątych i dziewięćdziesiątych XX stulecia. To właśnie stanowi zasadniczą zaletę pracy Iana Kershawa. Niewątpliwie jest ona jedną z najpoważniejszych syntez najnowszych dziejów Europy.

\section{Streszczenie}

Michał J. Zacharias przedstawia pracę brytyjskiego historyka Iana Kershawa, poświęconą dziejom Europy w drugiej połowie XX w. i w pierwszych dekadach kolejnego, XXI stulecia. Praca ma charakter syntetyczny. Należy podkreślić, że w ujęciu jej Autora dzieje Starego Kontynentu nie sa prostą sumą dziejów poszczególnych państw europejskich. Kershaw omawia przede wszystkim najpoważniejsze problemy i zjawiska historyczne epoki z perspektywy Europy. W jego rozważaniach liczą się głównie najważniejsze państwa i narody europejskie. Takie podejście nie jest pozbawione pewnej racji, bo przecież właśnie historia tych krajów najlepiej oświetla przyczyny i przebieg, znaczenie i następstwa skomplikowanych wydarzeń i procesów dziejowych. Niemniej takie ujęcie ma zarówno zalety, jak i wady, przedstawione w niniejszym artykule recenzyjnym. Niewątpliwie umożliwia zobrazowanie tak ważnych kwestii, jak powojenny podział Europy, „zimna wojna”, powojenna gospodarka, procesy integracyjne, kontestacja lat sześćdziesiątych, przemiany kulturowe i mentalne, kryzysy paliwowe z 1973 i 1979 r. i ich konsekwencje, kryzys i upadek „realnego socjalizmu”, neoliberalizm, globalizacja, zjednoczenie Niemiec, kryzys 2008 r. i jego następstwa, kryzysy w Europejskiej Wspólnocie Gospodarczej i Unii Europejskiej, kwestie społeczne, choć te ostatnie zostały przedstawione prawie wyłącznie z perspektywy Europy Zachodniej. Dokładne i wnikliwe przedstawienie tych zagadnień stanowi o wadze recenzowanej pracy. Niewątpliwie jest ona jedną z najpoważniejszych syntez najnowszych dziejów Europy. Niezależnie od 
widocznych słabości związanych głównie ze sposobem przedstawienia problematyki państw środkowoeuropejskich, w pewnym stopniu także Związu Sowieckiego, a później Rosji. Razi również ograniczenie opisu osiąnięć w dziedzinie kultury do tzw. złotego wieku kapitalizmu, a więc do pierwszych trzech powojennych dziesięcioleci, i to jedynie w Europie Zachodniej. $\mathrm{Z}$ pracy nic się nie dowiemy, jak one wyglądały w kolejnych dekadach. W syntezie dziejów Europy potrzeba przedstawienia tych dokonań wydaje się oczywista.

\section{The European Journey from Uncertainty to Insecurity: 1950-2017}

Michał J. Zacharias presents the work of the British historian Ian Kershaw, who devoted it to the history of Europe in the second half of the twentieth century and the first decades of the twenty-first century. The work is a synthesis. It should be emphasised here that in Kershaw's view, the history of the Old Continent is not a simple sum of the histories of individual European countries. In the first place, the British researcher discusses the most critical problems and historical phenomena from the European perspective, which in his reflections are the most important states and nations. This is not without a specific reason because their history best illuminates and explains the causes and course, significance and consequences of complex events and historical processes.

Nevertheless, this approach has both advantages and disadvantages, as presented in this review article. Undoubtedly, it makes it possible to illustrate such vital issues as the post-war division of Europe, the Cold War, the post-war economy, integration processes, the protest of the 1960s, cultural and mental transformations, the fuel crises of 1973 and 1979 with their consequences, the crisis and fall of 'real socialism', neoliberalism, globalisation, German reunification, the 2008 crisis and its implications, crises in the European Economic Community and the European Union, social issues; however, the latter are presented almost exclusively from a Western European perspective. A thorough and insightful presentation of these issues accounts for the importance of the reviewed work. It is undoubtedly one of the most profound syntheses of recent European history, regardless of its apparent weaknesses, which are mainly related to how are presented problems of Central European countries, and to some extent, the Soviet Union and later Russia. The limitation of the description of cultural achievements to the so-called golden age of capitalism, i.e. the first three post-war decades, and only in Western Europe, is also disappointing. We learn nothing from the book about how they looked in the following decades, while in a synthesis of European history, the need to present these achievements seems obvious.

\section{Bibliografia}

Aron R., Widz i uczestnik, z Raymondem Aronem rozmawiaja Jean-Louis Missika i Dominique Wolton, tłum. A. Zagajewski, Warszawa 1992.

Banac I., Post-Communism as Post Yugoslavism: The Yugoslav Non-Revolutions of 1989-1990, w: Eastern Europe in Revolution, red. I. Banac, Ithaca-London 1992.

Banac I., The National Question In Yugoslavia. Origins, History, Politics, Ithaca-London 1984. Beauvoir de S., Siła rzeczy, tłum. J. Pański, Warszawa 2009.

Cataluccio F.M., Sposób na imbecyla, „Wolna Sobota”, dodatek do „Gazety Wyborczej”, 2-3 I 2021 , s. 31.

Čuvalo A., The Croatian National Movement 1966-1972, Boulder 1990.

Đilas M., Nowa klasa. Analiza systemu komunistycznego, tłum. A. Lisowski, Nowy Jork 1958.

Eisler J., Marzec 1968. Geneza - przebieg - konsekwencje, Warszawa 1991.

Eisler J., Polski rok 1968, Warszawa 2006.

Fourastié J., Les Trente Glorieuses: ou la révolution invisible de 1946 à 1975, Paris 1979. 
Hobsbawm E., Wiek skrajności. Spojrzenie na Krótkie Dwudzieste Stulecie, tłum. J. Kalinowska-Król, M. Król, Warszawa 1999.

Judt T., Powojnie. Historia Europy od roku 1945, tłum. R. Bartołd, Poznań 2008.

Kershaw I., Do piekta i z powrotem. Europa 1914-1949, tłum. A. Romanek, Kraków 2016.

Kerhaw I., Rozdarty kontynent. Europa 1950-2017, tłum. T. Krzyżanowski, Kraków 2020.

Keynes J.M., The General Theory of Employment, Interest and Money, New York 1935.

Kołodko G., Wędrujacy świat, Warszawa 2008.

Kuźniar R., Pozimnowojenne dwudziestolecie 1989-2010. Stosunki międzynarodowe na przetomie XX i XXI wieku, Warszawa 2011.

Leder A., Prześniona rewolucja. Ćwiczenie z logiki historycznej, Warszawa 2014.

Mak G., W Europie. Podróże przez dwudziesty wiek, tłum. M. Woźniak-Diederen, Warszawa 2008.

Müller J.W., Przeciw demokracji. Idee polityczne XX wieku w Europie, tłum. J. Majmurek, Warszawa 2016.

Ost D., Klęska „Solidarności”. Gniew i polityka w postkomunistycznej Europie, Warszawa 2007.

Ramet P., Nationalism and Federalism in Yugoslavia, 1963-1983, Bloomington 1984.

Ramet S.P., Balkan Babel. The Disintegration of Yugoslavia. From the Death of Tito to the Fall of Milošević, Boulder 2002.

Roszkowski W., Roztrzaskane lustro. Upadek cywilizacji zachodniej, Kraków 2019.

Rusinov D., The Yugoslav Experiment 1958-1974, London 1974.

Sowa J., Fantomowe ciało króla. Peryferyjne zmagania z nowoczesna forma, Kraków 2011.

Toeplitz K.T., Najkrótsze stulecie. Szkic o XX wieku, Warszawa 2000.

Walicki A., Bez sprawiedliwości nie ma wolności, „Przegląd”, 9-15 XII 2013, s. 8-12.

Walicki A., Neoliberalna rewolucja, „Gazeta Wyborcza”, 31 XI - 1 XII 2013, s. 30-31.

Walicki A., Od projektu komunistycznego do neoliberalnej utopii, Kraków 2013.

Zacharias M.J., Idee, utopie, rzeczywistość. Myśl polityczna Milovana Đilasa (1911-1995), Bydgoszcz 2015.

Zacharias M.J., Komunizm, federacja, nacjonalizmy. System wtadzy w Jugostawii 1943-1991. Powstanie, przeksztatcenia, rozkład, Warszawa 2004.

Zacharias M.J., Pierwsza połowa XX stulecia. Europejska droga „do piekta i z powrotem”, „Dzieje Najnowsze” 2017, nr 4, s. 240-266.

Zaremba M., Wielka trwoga. Polska 1944-1947. Ludowa reakcja na kryzys, Kraków 2017.

Michał Jerzy Zacharias - prof. dr hab. W latach 1990-2007 pracował w Instytucie Historii Polskiej Akademii Nauk. Od 1999 r. związany z Wyższą Szkołą Pedagogiczną w Bydgoszczy (obecnie Uniwersytet Kazimierza Wielkiego), emerytowany pracownik Wydziału Nauk o Polityce i Administracji Uniwersytetu Kazimierza Wielkiego. Obszar zainteresowań: historia powszechna i Polski XX w., szczególnie polityka międzynarodowa, polska polityka zagraniczna, Jugosławia, elity polityczne, ustroje i myśl polityczna tego stulecia. E-mail: michal.j.zacharias@gmail.com.

Michał Jerzy Zacharias - professor emeritus of Kazimierz Wielki University in Bydgoszcz. In 1990-2007, employed at the Institute of History of the Polish Academy of Sciences. From 1999 on, associated with the Higher Teacher Education School in Bydgoszcz, which was transformed into the Bydgoszcz Academy and then into the Kazimierz Wielki University. He worked at the Political Science Institute of the University. His areas of interest cover: universal and Polish history of the 20th century, especially international politics, Polish foreign policy, Yugoslavia, elites, regimes and political thought of the 20th century. E-m a il: michal.j.zacharias@gmail.com. 